\title{
HETEROGENEOUS SHALLOW-SHELF CARBONATE BUILDUPS IN THE PARADOX BASIN, UTAH AND COLORADO: TARGETS FOR INCREASED OIL PRODUCTION AND RESERVES USING HORIZONTAL DRILLING TECHNIQUES
}

\section{SEMI-ANNUAL \\ TECHNICAL PROGRESS REPORT \\ October 6, 2002 - April 5, 2003}

\author{
by \\ David E. Eby, Eby Petrography \& Consulting, Inc. \\ and \\ Thomas C. Chidsey, Jr., Principal Investigator/Program Manager \\ Kevin McClure \\ Craig D. Morgan \\ Utah Geological Survey

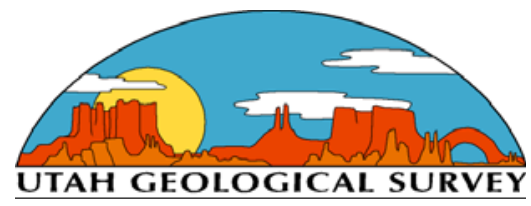 \\ July 2003
}

Contract No. DE-FC26-00BC15128

Gary D. Walker, Contract Manager

U.S. Department of Energy

National Petroleum Technology Office

1 West $3^{\text {rd }}$ Street

Tulsa, OK 74103-3532 


\section{DISCLAIMER}

This report was prepared as an account of work sponsored by an agency of the United States Government. Neither the United States Government nor any agency thereof, nor any of their employees, makes any warranty, express or implied, or assumes any legal liability or responsibility for the accuracy, completeness, or usefulness of any information, apparatus, product, or process disclosed, or represents that its use would not infringe privately owned rights. Reference herein to any specific commercial product, process, or service by trade name, trademark, manufacturer, or otherwise does not necessarily constitute or imply its endorsement, recommendation, or favoring by the United States Government or any agency thereof. The views and opinions of authors expressed herein do not necessarily state or reflect those of the United States Government or any agency thereof. 


\title{
HETEROGENEOUS SHALLOW-SHELF CARBONATE BUILDUPS IN THE PARADOX BASIN, UTAH AND COLORADO: TARGETS FOR INCREASED OIL PRODUCTION AND RESERVES USING HORIZONTAL DRILLING TECHNIQUES
}

\author{
SEMI-ANNUAL \\ TECHNICAL PROGRESS REPORT \\ October 6, 2002 - April 5, 2003 \\ by
}

David E. Eby, Eby Petrography \& Consulting, Inc.

and

Thomas C. Chidsey, Jr., Principal Investigator/Program Manager

Craig D. Morgan

Kevin Mcclure

Utah Geological Survey

Date of Report: July 2003

\section{Contract No. DE-FC26-00BC15128}

\author{
Gary D. Walker, Contract Manager \\ U.S. Department of Energy \\ National Petroleum Technology Office \\ 1 West $3^{\text {rd }}$ Street \\ Tulsa, OK 74103-3532
}

Submitting Organization: Utah Geological Survey

1594 West North Temple, Suite 3110

P.O. Box 146100

Salt Lake City, Utah 84114-6100

(801) 537-3300

US/DOE Patent Clearance is not required prior to the publication of this document. 


\section{CONTENTS}

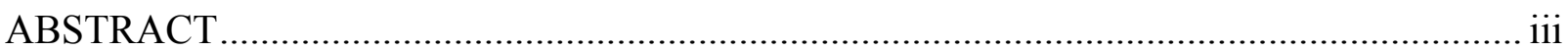

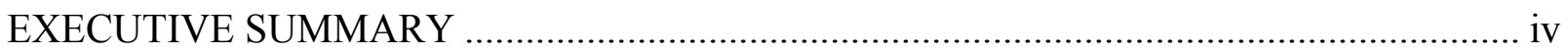

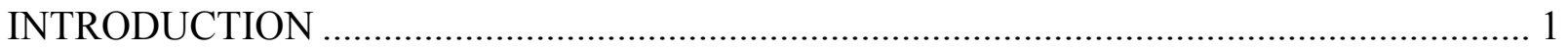

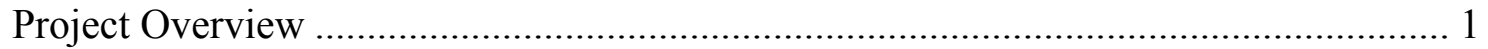

Project Benefits and Potential Application ................................................................. 4

REGIONAL FACIES TRENDS IN THE UPPER ISMAY AND LOWER DESERT CREEK ZONES OF THE BLANDING SUB-BASIN OF THE PARADOX BASIN, UTAH - RESULTS

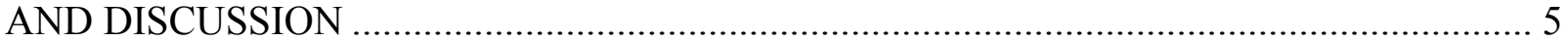

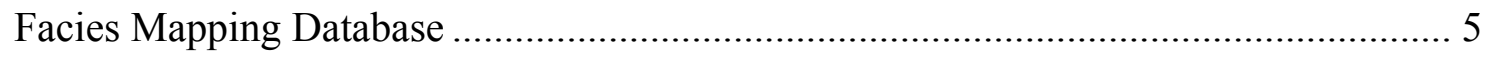

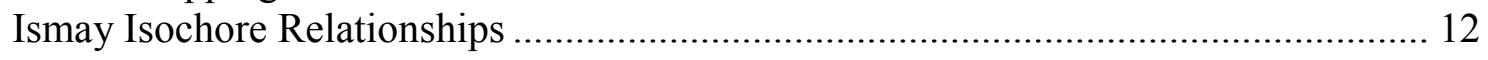

Upper Ismay “Clean Carbonate” Isochore Map ……………………………..... 12

Upper Ismay "Anhydrite 2" Isochore .............................................................. 12

Isochore "Dilemma" ............................................................................... 12

Major Facies Mapped in the Upper Ismay and Lower Desert Creek Zones.................. 14

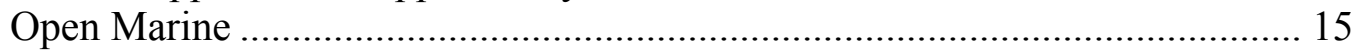

Middle Shelf............................................................................................ 16

Inner Shelf/Tidal Flat............................................................................ 18

Bryozoan Mounds ..................................................................................... 20

Proto-Mounds/Collapse Breccia ..................................................................... 20

Phylloid-Algal Mounds............................................................................. 21

Quartz Sand Dunes ……………………………………………………. 23

Anhydritic Salinas ....................................................................................... 23

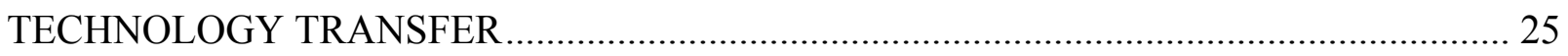

Utah Geological Survey Survey Notes and Internet Web Site...................................... 26

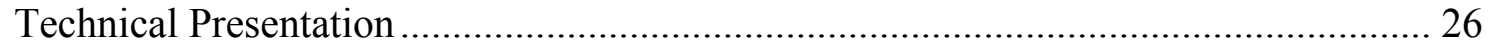

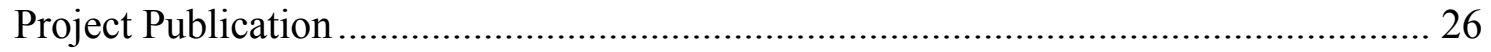

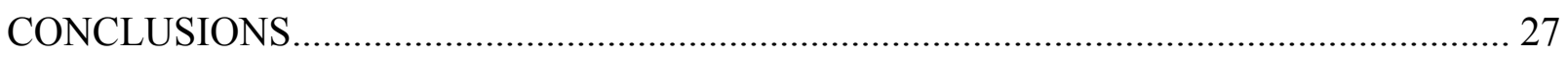

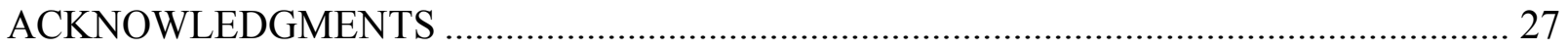

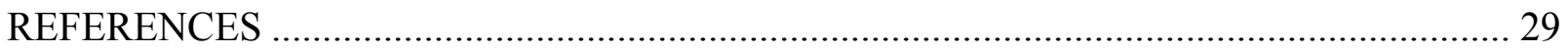




\section{FIGURES}

Figure 1. Map showing project study area and fields within the Ismay and Desert Creek producing trends, Utah and Colorado 1

Figure 2. Pennsylvanian stratigraphy of the southern Paradox Basin .................................... 2

Figure 3. Block diagrams displaying major depositional facies for the Ismay (A) and Desert Creek (B) zones, Pennsylvanian Paradox Formation ................................................. 3

Figure 4. Southwest-northeast cross section through the Blanding sub-basin showing regional Ismay and Desert Creek correlations

Figure 5. Northwest-southeast cross section through the Blanding sub-basin showing regional Ismay and Desert Creek correlations

Figure 6. Type log for the Cherokee field showing the Ismay and Desert Creek correlation scheme, major units, and productive.

Figure 7. Type log for the Bug field mound, showing the Desert Creek correlation scheme, major units, and productive interval

Figure 8. Type log for the Bug field off-mound area, showing the Desert Creek correlation

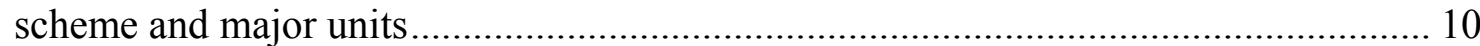

Figure 9. Isochore map of the upper Ismay clean carbonate interval ................................. 13

Figure 10. Isochore map of the upper Ismay "anhydrite 2" ........................................... 13

Figure 11. Regional facies map of the upper part of the upper Ismay zone ......................... 14

Figure 12. Regional facies map of the lower part of the upper Ismay zone ......................... 15

Figure 13. Regional facies map of the lower Desert Creek zone...................................... 16

Figure 14. Core photographs showing typical Ismay open-marine facies............................. 17

Figure 15. Core photograph showing typical Desert Creek open-marine facies ................... 17

Figure 16. Core photographs showing typical Ismay and Desert Creek middle-shelf facies ... 18

Figure 17. Core photographs showing typical Ismay inner shelf/tidal flat facies .................. 19

Figure 18. Core photograph showing typical Ismay bryozoan-mound facies ....................... 20

Figure 19. Core photograph showing typical Desert Creek proto-mound/collapse breccia ..... 21

Figure 20. Core photographs showing typical Ismay and Desert Creek phylloid-algal mound

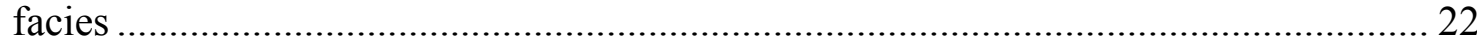

Figure 21. Core photograph showing typical upper Ismay quartz sand dune facies .............. 23

Figure 22. Core photographs showing anhydrite growth forms typically found in anhydite salina facies of upper Ismay intra-shelf basins ..................................................... 24

Figure 23. Map view of an ideal upper Ismay, intra-shelf basin surrounded by a ring of inner shelf/tidal flat sediments encasing phylloid-algal mound clusters ............................. 28

Figure 24. Cut-away block diagram showing spatial relationships of upper Ismay facies controlled by an intra-shelf basin and a hypothetical vertical well used as a kick-off location for horizontal drilling into previously undrained mounds 28

\section{TABLES}

Table 1. Correlation scheme used for Ismay and Desert Creek zones of the Paradox Formation in Cherokee and Bug fields, Blanding sub-basin, Utah.... 


\begin{abstract}
The Paradox Basin of Utah, Colorado, Arizona, and New Mexico contains nearly 100 small oil fields producing from carbonate buildups within the Pennsylvanian (Desmoinesian) Paradox Formation. These fields typically have one to 10 wells with primary production ranging from 700,000 to 2,000,000 barrels $\left(111,300-318,000 \mathrm{~m}^{3}\right)$ of oil per field and a 15 to 20 percent recovery rate. At least 200 million barrels $\left(31.8\right.$ million $\left.\mathrm{m}^{3}\right)$ of oil will not be recovered from these small fields because of inefficient recovery practices and undrained heterogeneous reservoirs.

Several fields in southeastern Utah and southwestern Colorado are being evaluated as candidates for horizontal drilling and enhanced oil recovery from existing vertical wells based upon geological characterization and reservoir modeling case studies. Geological characterization on a local scale is focused on reservoir heterogeneity, quality, and lateral continuity, as well as possible reservoir compartmentalization, within these fields. This study utilizes representative cores, geophysical logs, and thin sections to characterize and grade each field's potential for drilling horizontal laterals from existing development wells. The results of these studies can be applied to similar fields elsewhere in the Paradox Basin and the Rocky Mountain region, the Michigan and Illinois Basins, and the Midcontinent region.

This report covers research activities for the second half of the third project year (October 6, 2002, through April 5, 2003). The primary work included describing and mapping regional facies of the upper Ismay and lower Desert Creek zones of the Paradox Formation in the Blanding sub-basin, Utah.

Regional cross sections show the development of "clean carbonate" packages that contain all of the productive reservoir facies. These clean carbonates abruptly change laterally into thick anhydrite packages that filled several small intra-shelf basins in the upper Ismay zone.

Examination of upper Ismay cores identified seven depositional facies: open marine, middle shelf, inner shelf/tidal flat, bryozoan mounds, phylloid-algal mounds, quartz sand dunes, and anhydritic salinas. Lower Desert Creek facies include open marine, middle shelf, protomounds/collapse breccia, and phylloid-algal mounds.

Mapping the upper Ismay zone facies delineates very prospective reservoir trends that contain porous, productive buildups around the anhydrite-filled intra-shelf basins. Facies and reservoir controls imposed by the anhydritic intra-shelf basins should be considered when selecting the optimal location and orientation of any horizontal drilling from known phylloidalgal reservoirs to undrained reserves, as well as identifying new exploration trends. Although intra-shelf basins are not present in the lower Desert Creek zone of the Blanding sub-basin, drilling horizontally along linear shoreline trends could also encounter previously undrilled, porous intervals and buildups.

Technology transfer activities consisted of a technical presentation at a Class II Review conference sponsored by the National Energy Technology Laboratory at the Center for Energy and Economic Diversification in Odessa, Texas. The project home page was updated on the Utah Geological Survey Internet web site.
\end{abstract}




\section{EXECUTIVE SUMMARY}

The project's primary objective is to enhance domestic petroleum production by demonstration and transfer of horizontal drilling technology in the Paradox Basin of Utah and Colorado. If this project can demonstrate technical and economic feasibility, then the technique can be applied to approximately 100 additional small fields in the Paradox Basin alone, and result in increased recovery of 25 to 50 million barrels $\left(4-8\right.$ million $\left.\mathrm{m}^{3}\right)$ of oil. This project is designed to characterize several shallow-shelf, carbonate reservoirs in the Pennsylvanian (Desmoinesian) Paradox Formation, choose the best candidate field(s) for a pilot demonstration project to drill horizontally from existing vertical wells, monitor well performance(s), and report associated validation activities.

The Utah Geological Survey heads a multidisciplinary team to determine the geological and reservoir characteristics of typical, small, shallow-shelf, carbonate reservoirs in the Paradox Basin. The Paradox Basin technical team consists of the Utah Geological Survey (prime contractor), Colorado Geological Survey (subcontractor), Eby Petrography \& Consulting Inc. (subcontractor), and Seeley Oil Company (subcontractor and industry partner). This research is funded by the Class II Oil Revisit Program of the U.S. Department of Energy, National Petroleum Technology Office (NPTO) in Tulsa, Oklahoma. This report covers research activities for the second half of the third project year (October 6, 2002, through April 5, 2003). This primary work included describing and mapping regional facies of the upper Ismay and lower Desert Creek zones of the Paradox Formation in the Blanding sub-basin, Utah. From these, and other, project evaluations, untested or under-produced reservoir compartments and trends can be identified as targets for horizontal drilling. The results of this study can be applied to similar reservoirs in many U.S. basins.

A grid of regional, log cross sections within the Utah portion of the Blanding sub-basin was constructed using a project-developed correlation scheme. The cross sections show the development of "clean carbonate" packages that contain all of the productive reservoir facies. These clean carbonates abruptly change laterally into thick anhydrite packages. Isochore maps of the upper Ismay clean carbonates and the locally thick anhydrites are consistent with a broad carbonate shelf containing several small intra-shelf basins.

Examination of upper Ismay cores identified seven depositional facies: open marine, middle shelf, inner shelf/tidal flat, bryozoan mounds, phylloid-algal mounds, quartz sand dunes, and anhydritic salinas. Lower Desert Creek facies include open marine, middle shelf, protomounds/collapse breccia, and phylloid-algal mounds.

Mapping the upper Ismay zone facies into two intervals (upper and lower parts) delineates very prospective reservoir trends that contain porous, productive buildups. The mapped facies trends clearly define anhydrite-filled intra-shelf basins. Facies and reservoir controls imposed by the anhydritic intra-shelf basins should be considered when selecting the optimal location and orientation of any horizontal drilling for undrained reserves, as well as identifying new exploration trends. Projections of the inner shelf/tidal flat and mound trends around the intra-shelf basins identify potential exploration targets, which could be developed using horizontal drilling techniques. Drilling horizontally from known phylloid-algal reservoirs along the inner shelf/tidal flat trend could encounter previously undrilled porous buildups. Intra-shelf basins are not present in the lower Desert Creek zone of the Blanding sub-basin. However, drilling horizontally from productive mound facies along linear shoreline trends could also encounter previously undrilled porous Desert Creek intervals and buildups. 
Technology transfer activities consisted of a technical presentation at a Class II Review conference sponsored by the National Energy Technology Laboratory at the Center for Energy and Economic Diversification in Odessa, Texas. Core photographs, scanning electron microscope images, pore casts, photomicrographs, capillary pressure/mercury injection graphs, maps, diagenetic analysis, and horizontal drilling recommendations were part of the presentation. The project home page was updated on the Utah Geological Survey Internet web site. The project team planned a project short course, co-sponsored by the U.S. Department of Energy, for members of the American Association of Petroleum Geologists at the 2003 Annual Convention in Salt Lake City, Utah. Project team members also published semi-annual reports detailing project progress and results. 


\section{INTRODUCTION}

\section{Project Overview}

Over 400 million barrels ( 64 million $\mathrm{m}^{3}$ ) of oil have been produced from the shallowshelf carbonate reservoirs in the Pennsylvanian Paradox Formation in the Paradox Basin of southeastern Utah and southwestern Colorado (figure 1). The two main producing zones of the

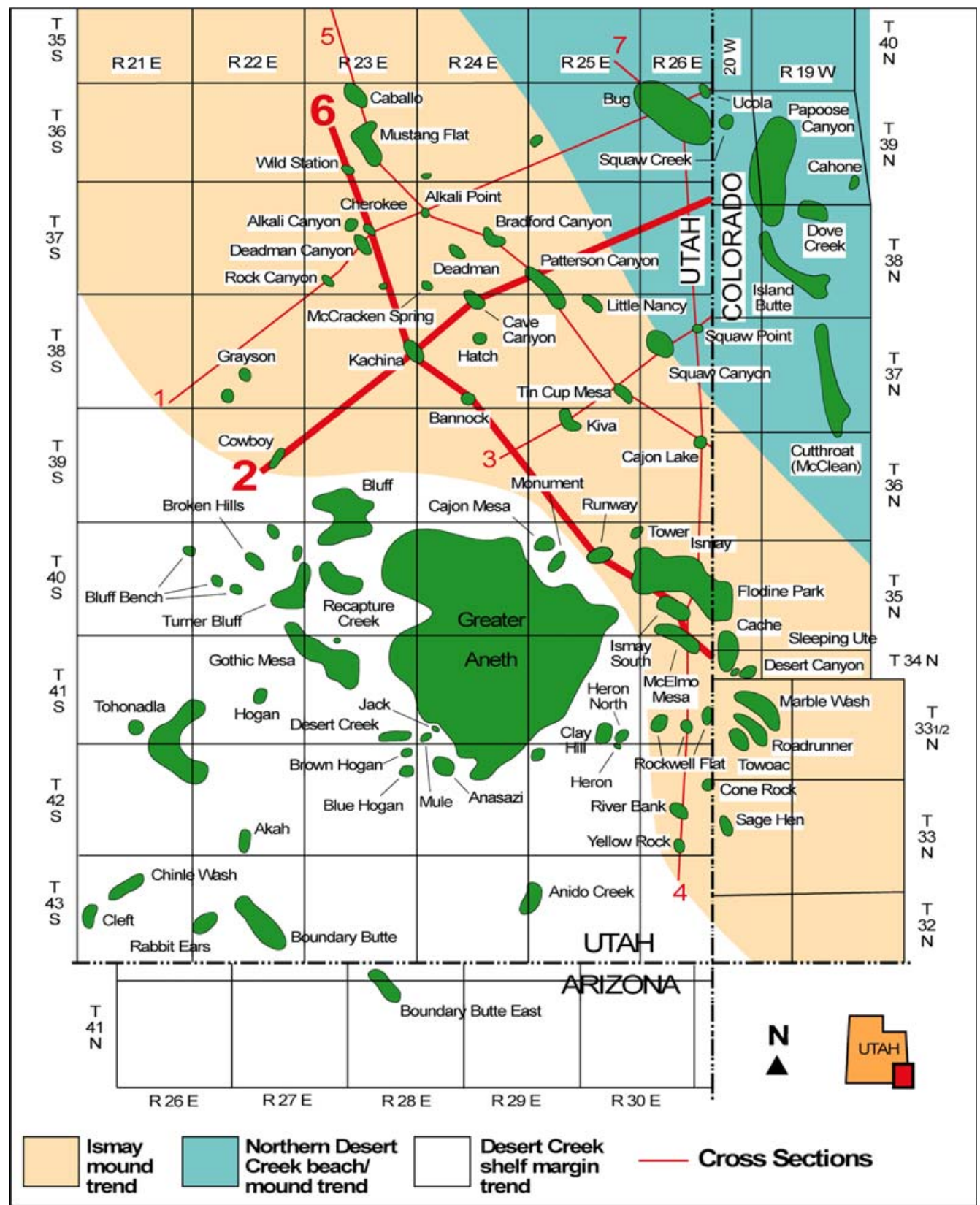

Figure 1. The project study area and fields within the Ismay and Desert Creek producing trends in the Blanding sub-basin, Utah and Colorado (red lines designate cross section locations generated in this study [cross sections 2 and 6 are shown on figures 4 and 5]). 
Paradox Formation are informally named the Ismay and the Desert Creek (figure 2). Reservoirs within the Utah portion of the upper Ismay zone of the Paradox Formation are dominantly limestones composed of small, phylloid-algal buildups; locally variable, inner-shelf, skeletal calcarenites; and rare, open-marine, bryozoan mounds (figure 3A). The Ismay produces oil from fields in the southern Blanding sub-basin (figure 1). The Desert Creek zone is dominantly dolomite comprising regional, nearshore, shoreline trends with highly aligned, linear facies tracts (figure 3B). The Desert Creek produces oil in fields in the central Blanding sub-basin (figure 1). Both the Ismay and Desert Creek buildups generally trend northwest-southeast. Various facies changes and extensive diagenesis have created complex reservoir heterogeneity within these two diverse zones.

With the exception of the giant Greater Aneth field, the other 100-plus oil fields in the basin typically contain 2 to 10 million barrels (0.3-1.6 million $\left.\mathrm{m}^{3}\right)$ of original oil in place. Most of these fields are characterized by high initial production rates followed by a very short productive life (primary), and hence premature abandonment. Only 15 to 25 percent of the original oil in place is recoverable during primary production from conventional vertical wells.

\section{West}

East

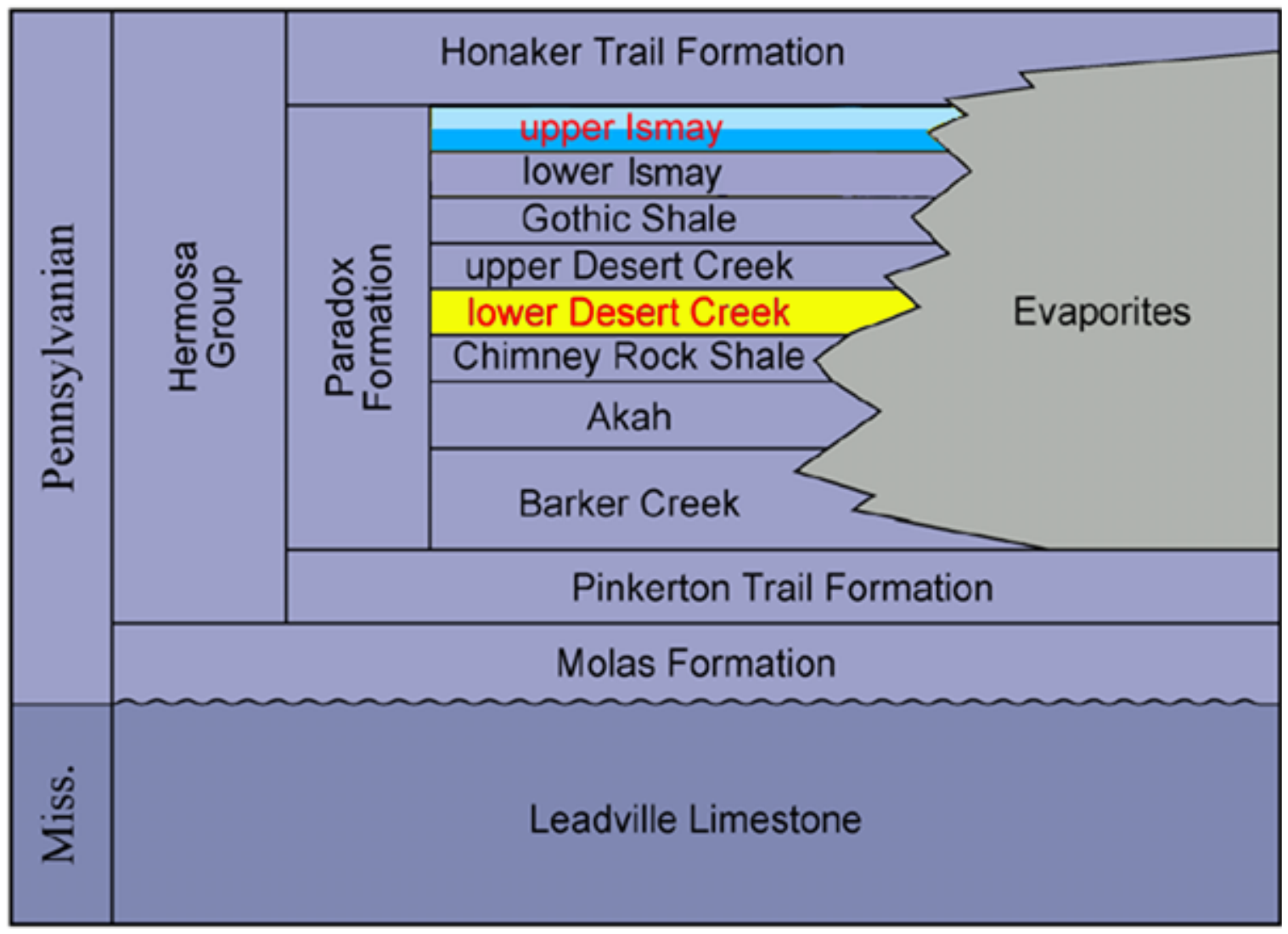

Figure 2. Pennsylvanian stratigraphy of the southern Paradox Basin including informal zones of the Paradox Formation; the upper Ismay and lower Desert Creek zones productive in case-study fields are highlighted. For this study the upper Ismay zone has been further divided into two units - the "upper part" and the "lower part." 

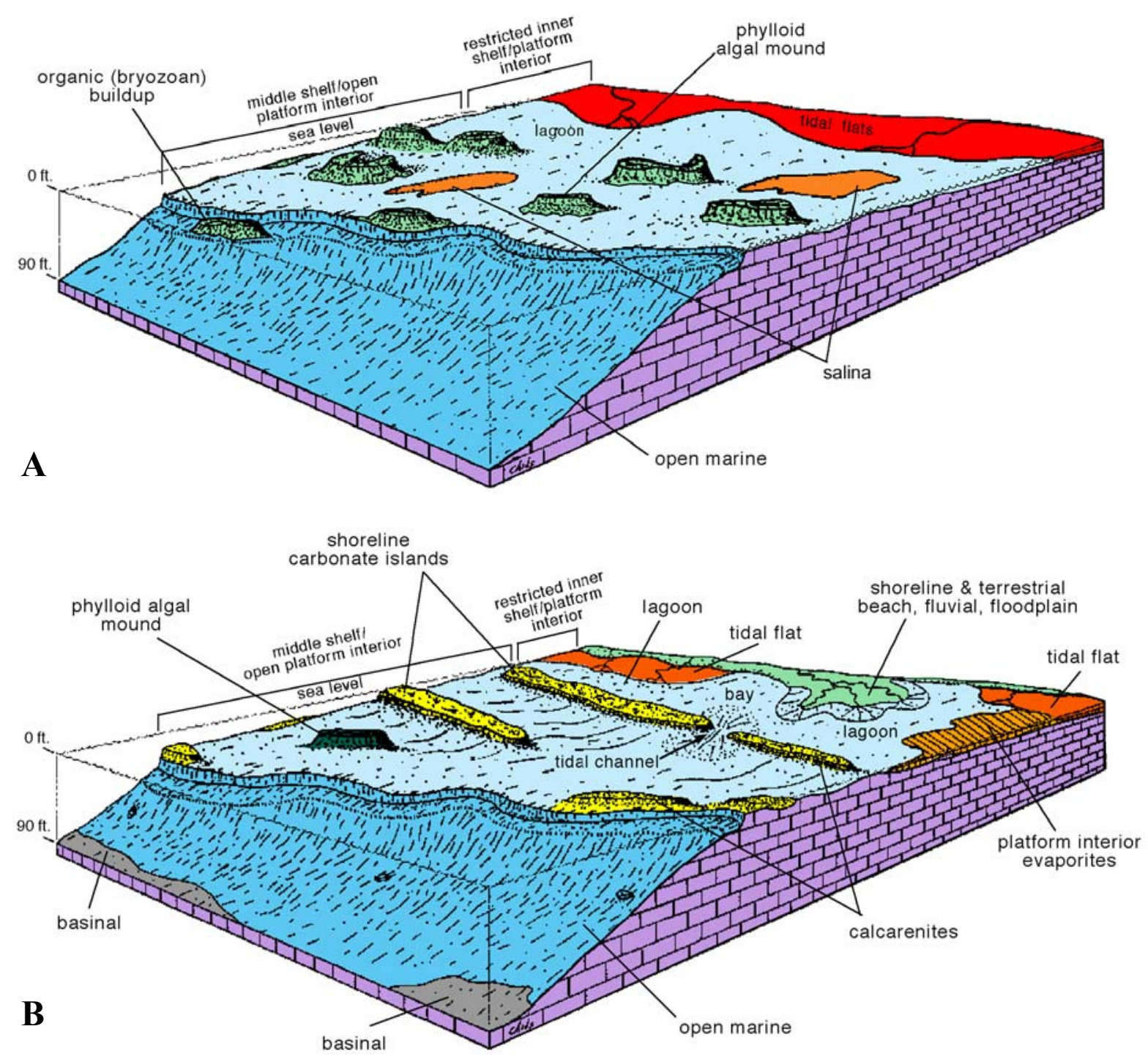

Figure 3. Block diagrams displaying major depositional facies, as determined from core, for the Ismay (A) and Desert Creek (B) zones, Pennsylvanian Paradox Formation, Utah and Colorado (tan and blue areas shown in figure 1).

An extensive and successful horizontal drilling program has been conducted in the giant Greater Aneth field. However, to date, only two horizontal wells have been drilled in small Ismay and Desert Creek fields. The results from these wells were disappointing due to poor understanding of the carbonate facies and diagenetic fabrics that create reservoir heterogeneity. These small fields, and similar fields in the basin, are at high risk of premature abandonment. At least 200 million barrels $\left(31.8\right.$ million $\left.\mathrm{m}^{3}\right)$ of oil will be left behind in these small fields because current development practices leave compartments of the heterogeneous reservoirs undrained. Through proper geological evaluation of the reservoirs, production may be increased by 20 to 50 percent through the drilling of low-cost, single, or multilateral, horizontal legs from existing vertical development wells. In addition, horizontal drilling from existing wells minimizes surface disturbances and costs for field development, particularly in the environmentally sensitive areas of southeastern Utah and southwestern Colorado. 
The Utah Geological Survey (UGS), Colorado Geological Survey (CGS), Eby Petrography \& Consulting, Inc., and Seeley Oil Company have entered into a cooperative agreement with the U.S. Department of Energy (DOE) as part of its Class II Oil Revisit Program. A three-phase, multidisciplinary approach will be used to increase production and reserves from the shallow-shelf carbonate reservoirs in the Ismay and Desert Creek zones of the Paradox Basin.

Phase 1 is the geological and reservoir characterization of selected, diversified, small fields, including Cherokee and Bug fields in San Juan County, Utah (figure 1), to identify those field(s) having the greatest potential as targets for increased well productivity and ultimate recovery in a pilot demonstration project. This phase will include: (a) determination of regional geological setting; (b) analysis of the reservoir heterogeneity, quality, lateral continuity, and compartmentalization within the fields; (c) construction of lithologic, microfacies, porosity, permeability, and net pay maps of the fields; (d) determination of field reserves and recovery; and (e) integration of geological data in the design of single or multiple horizontal laterals from existing vertical wells.

Phase 2 is a field demonstration project of the horizontal drilling techniques identified as having the greatest potential for increased field productivity and ultimate recovery. The demonstration project will involve drilling one or more horizontal laterals from the existing vertical field well(s) to maximize production from the zones of greatest potential.

Phase 3 includes: (a) reservoir management and production monitoring, (b) economic evaluation of the results, and (c) determination of the ability to transfer project technologies to other similar fields in the Paradox Basin and throughout the U.S.

Phases 1, 2, and 3 will have continuous, but separate, technical transfer activities including: (a) an industry outreach program; (b) a core workshop/seminar in Salt Lake City; (c) publications and technical presentations; (d) a project home page on the Utah Geological Survey and Colorado Geological Survey Internet web sites; (e) digital databases, maps, and reports; (f) a summary of regulatory, economic, and financial needs; and (g) annual meetings with a Technical Advisory Board and Stake Holders Board.

\section{Project Benefits and Potential Application}

The overall benefit of this multi-year project would be enhanced domestic petroleum production by demonstrating and transferring an advanced-oil-recovery technology throughout the small oil fields of the Paradox Basin. Specifically, the benefits expected from the project are: (1) increasing recovery and reserve base by identifying untapped compartments created by reservoir heterogeneity; (2) preventing premature abandonment of numerous small fields; (3) increasing deliverability by horizontally drilling along the reservoir's optimal fluid-flow paths; (4) identifying reservoir trends for field extension drilling and stimulating exploration in Paradox Basin fairways; (5) reducing development costs by more closely delineating minimum field size and other parameters necessary for horizontal drilling; (6) allowing for minimal surface disturbance by drilling from existing, vertical, field well pads; (7) allowing limited energy investment dollars to be used more productively; and (8) increasing royalty income to the federal, state, and local governments, the Ute Mountain Ute Indian Tribe, and fee owners. These benefits may also apply to other areas including: algal-mound and carbonate buildup reservoirs on the eastern and northwestern shelves of the Permian Basin in Texas, Silurian pinnacle and patch reefs of the Michigan and Illinois Basins, and shoaling carbonate island trends of the Williston Basin. 
The results of this project are transferred to industry and other researchers through establishment of Technical Advisory and Stake Holders Boards, an industry outreach program, digital project databases, and project web pages. Project results will be disseminated via technical workshops and seminars, field trips, technical presentations at national and regional professional meetings, and papers in various technical or trade journals.

\section{REGIONAL FACIES TRENDS IN THE UPPER ISMAY AND LOWER DESERT CREEK ZONES OF THE BLANDING SUB-BASIN OF THE PARADOX BASIN, UTAH - RESULTS AND DISCUSSION}

Regional subsurface mapping of depositional facies for the two productive intervals of the upper Ismay and lower Desert Creek zones shows considerable spatial heterogeneity of the reservoir and non-reservoir rock types. In the Ismay, the location and shape of several anhydrite-rich, intra-shelf basins play major roles in the deposition and orientation of productive phylloid-algal buildups, as well as the shoreline facies that wrap around these evaporite basins. Facies distal from the anhydrite-filled basins generally contain less favorable reservoir rocks, whereas most phylloid-algal buildups and porous inner-shelf facies are very close to the intra-shelf basins. The two mapped, upper Ismay zone intervals show considerable differences in the distribution of these anhydrite basins and their surrounding facies. The Desert Creek zone in the Blanding sub-basin contains several of the same facies as the Ismay zone, the most notable exception being the intra-shelf evaporite basins which are discussed later.

\section{Facies Mapping Database}

A grid of regional geophysical well-log cross sections (figures 4 and 5), thickness relationships of important stratigraphic intervals, and facies types were combined with examination of cores throughout the Blanding sub-basin to provide a significant database for identifying potential targets for horizontal drilling within the small, heterogeneous, phylloidalgal buildups and associated facies in the upper Ismay and lower Desert Creek zones. The study area covers about 750 square miles $\left(1,900 \mathrm{~km}^{2}\right)$ within the Blanding sub-basin of the Paradox Basin. The total number of wells drilled to the Paradox Formation within the study area is about 480 wells. We interpreted all available cores in the area -41 wells in the upper part of the upper Ismay; 40 wells in the lower part of the upper Ismay; and 44 wells in the lower Desert Creek. Additionally, 82 geophysical well logs were interpreted from the upper Ismay and 38 from the Desert Creek.

Regional facies and isochore maps, and cross sections were constructed using a correlation scheme developed early in the project. This correlation scheme tied the corederived, typical, vertical sequence or cycle of depositional facies from the Cherokee and Bug case-study fields to the corresponding gamma-ray and neutron-density curves from geophysical well logs. The correlation scheme identified the major zone contacts, seals or barriers, baffles, producing or potential reservoirs, and depositional facies (figures 6,7 , and 8 , and table 1). 


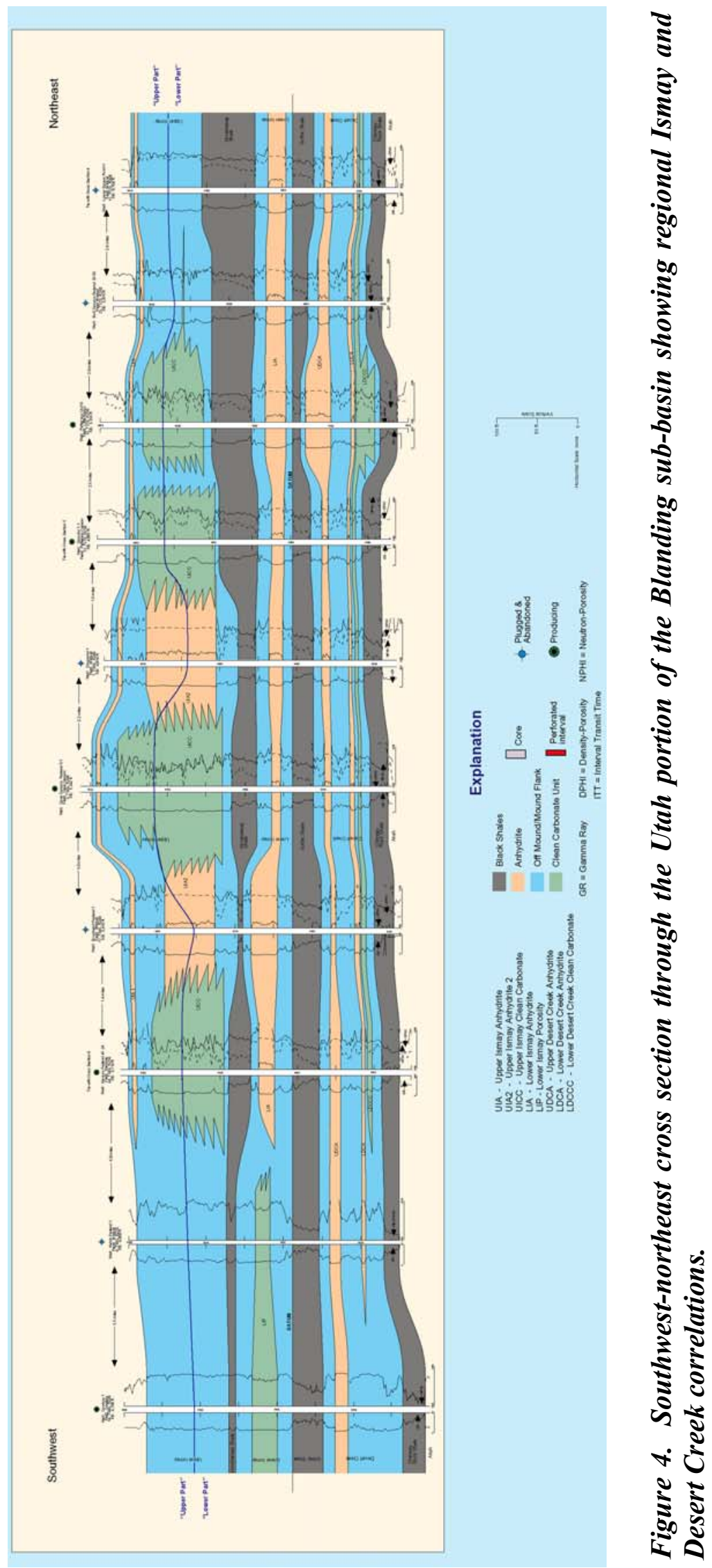




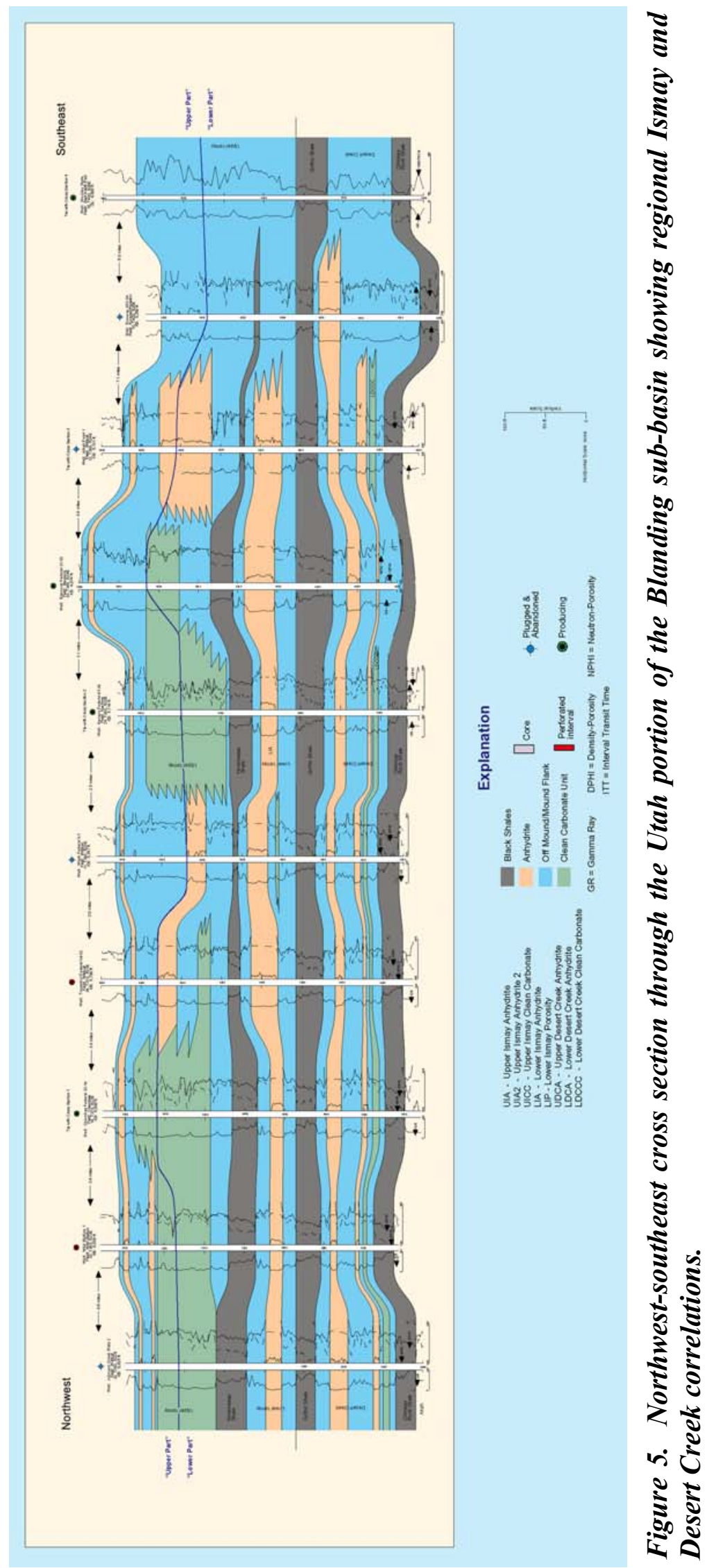




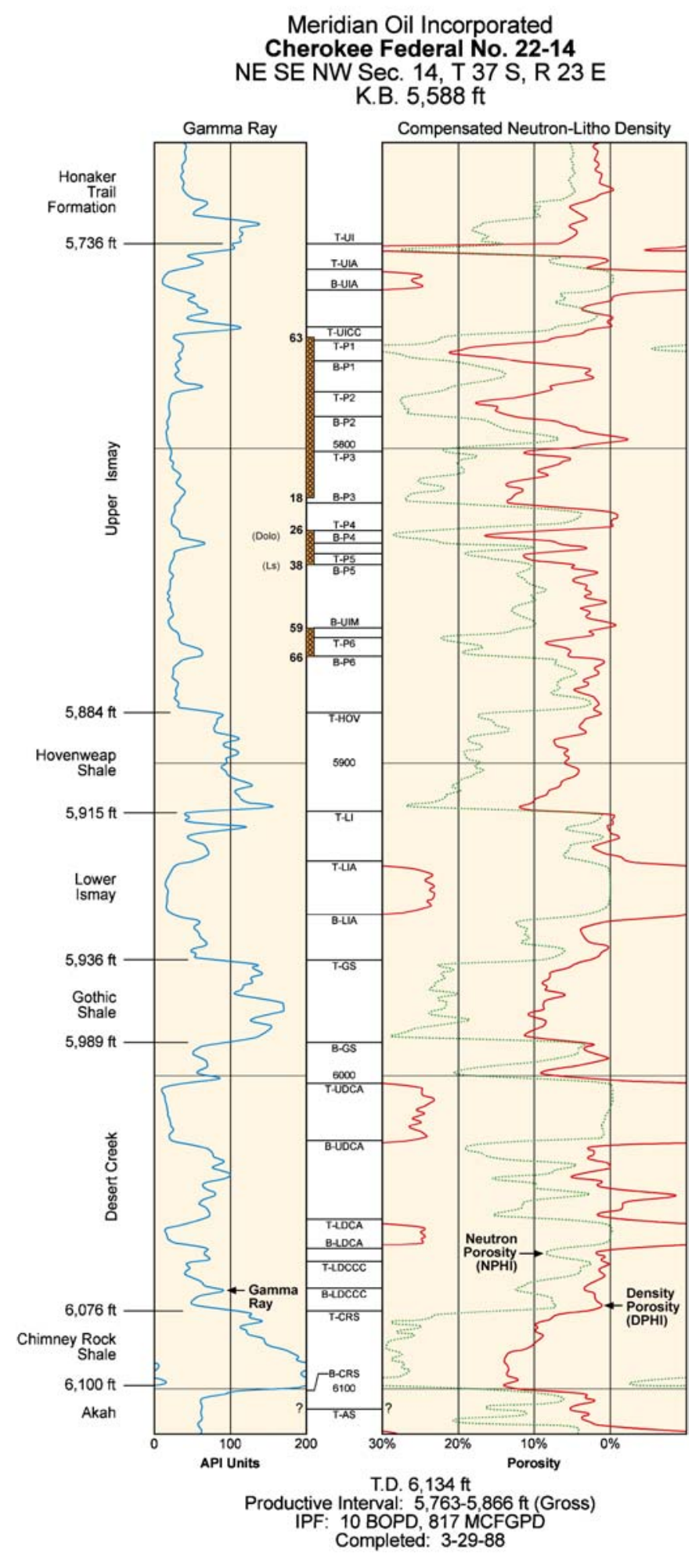

Figure 6. Type log for the Cherokee field (gamma-ray, compensated neutronlitho density) from the Cherokee Federal No. 22-14 well, showing the Ismay and Desert Creek correlation scheme, major units, and productive intervals (refer to table 1 for explanation of unit abbreviations). 


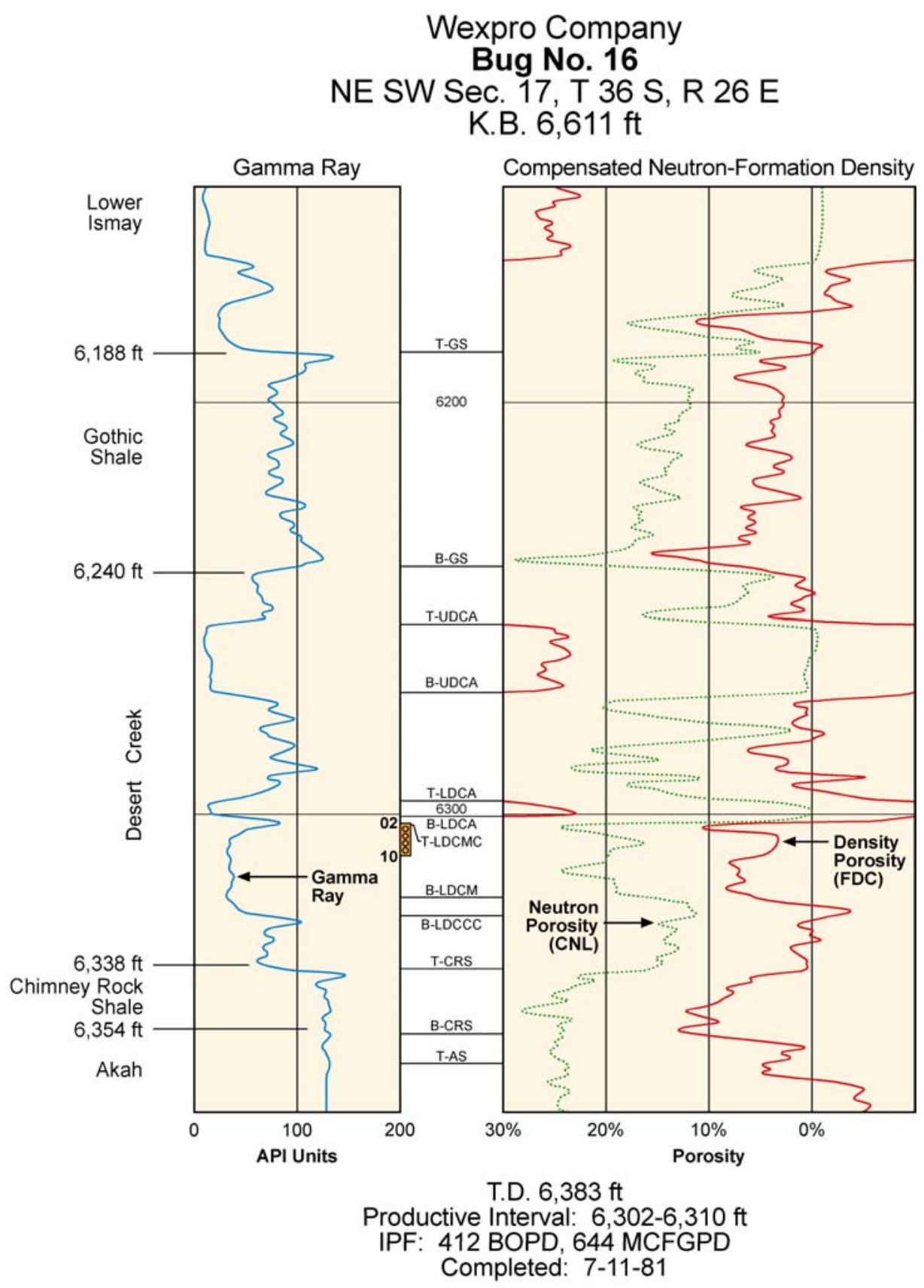

Figure 7. Type log for the Bug field mound (gamma-ray, compensated neutron-formation density) from the Bug No. 16 well, showing the Desert Creek correlation scheme, major units, and productive interval (refer to table 1 for explanation of unit abbreviations). 


\section{Wexpro Company Bug No. 7A \\ SW NE Sec. 7, T 36 S, R 26 E K.B. $6,665 \mathrm{ft}$}

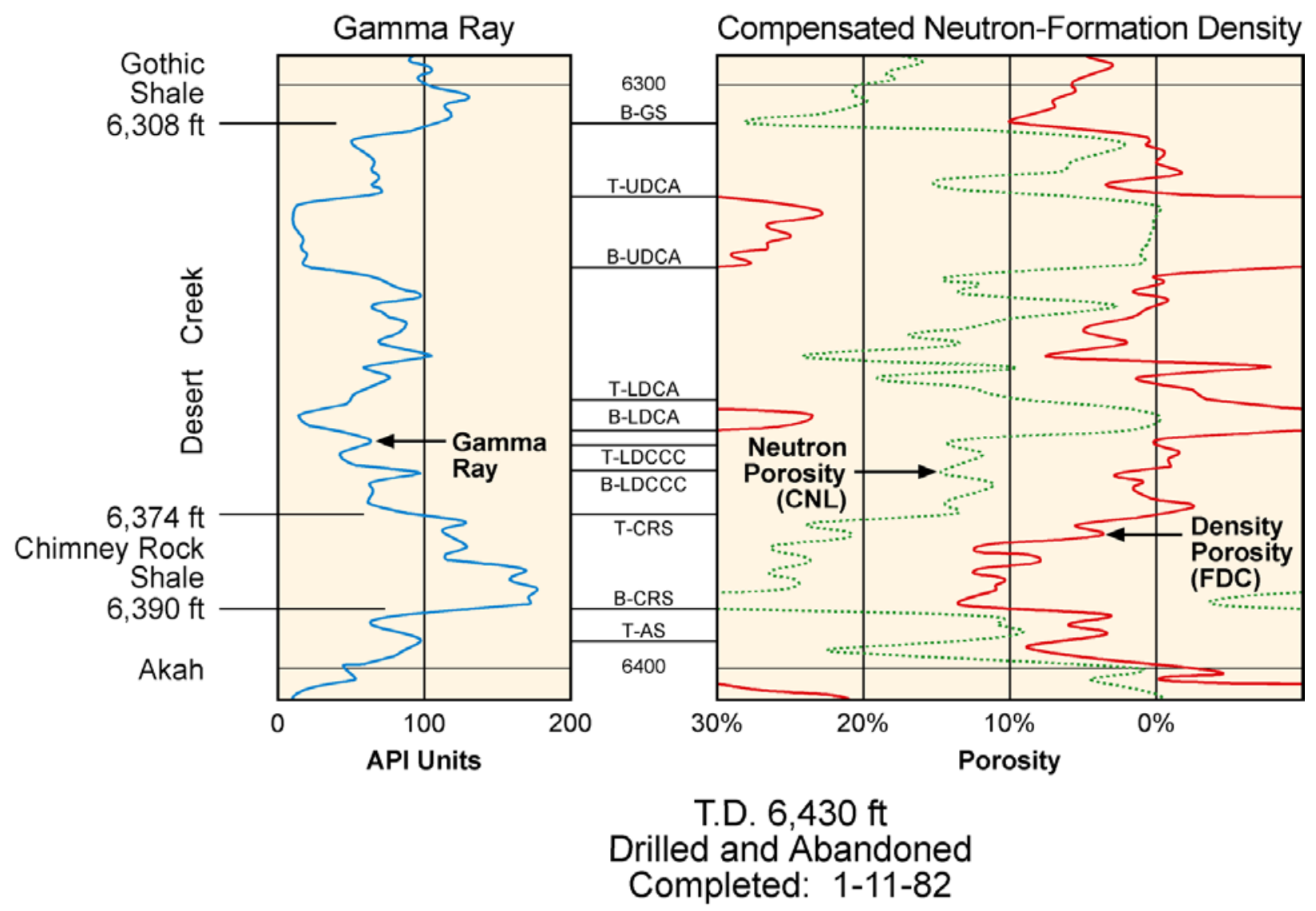

Figure 8. Type log for the Bug field off-mound area (gamma-ray, compensated neutronformation density) from the Bug No. $7 A$ well, showing the Desert Creek correlation scheme and major units (refer to table 1 for explanation of unit abbreviations). 
Table 1. Correlation scheme used for Ismay and Desert Creek zones of the Paradox Formation in Cherokee and Bug fields, Blanding sub-basin, Utah.

\begin{tabular}{|c|c|}
\hline Unit Code & Description \\
\hline T-UI & Top - Upper Ismay Zone \\
\hline T-UIA & Top - Upper Ismay Anhydrite \\
\hline B-UIA & Base - Upper Ismay Anhydrite \\
\hline T-UIA2 & Top - Upper Ismay Anhydrite 2 \\
\hline B-UIA2 & Base - Upper Ismay Anhydrite 2 \\
\hline T-UICC & Top - Upper Ismay Clean Carbonate \\
\hline T-P1 & Top - Porosity Unit \#1 \\
\hline B-P1 & Base - Porosity Unit \#1 \\
\hline T-P2 & Top - Porosity Unit \#2 \\
\hline B-P2 & Base - Porosity Unit \#2 \\
\hline T-P3 & Top - Porosity Unit \#3 \\
\hline B-P3 & Base - Porosity Unit \#3 \\
\hline T-P4 & Top - Porosity Unit \#4 \\
\hline B-P4 & Base - Porosity Unit \#4 \\
\hline T-P5 & Top - Porosity Unit \#5 \\
\hline B-P5 & Base - Porosity Unit \#5 \\
\hline B-UIM & Base - Upper Ismay Mound \\
\hline B-UICC & Base Upper Ismay Clean Carbonate \\
\hline T-P6 & Top - Porosity Unit \#6 \\
\hline B-P6 & Base - Porosity Unit \#6 \\
\hline T-HOV & Top - Hovenweap Shale \\
\hline$\overline{T-L I}$ & Top - Lower Ismay Zone \\
\hline T-LIA & Top - Lower Ismay Anhydrite \\
\hline$B-L I A$ & Base - Lower Ismay Anhydrite \\
\hline T-GS & Top - Gothic Shale \\
\hline B-GS & Base - Gothic Shale \\
\hline T-UDCA & Top - Upper Desert Creek Anhydrite \\
\hline B-UDCA & Base - Upper Desert Creek Anhydrite \\
\hline T-LDCA & Top - Lower Desert Creek Anhydrite \\
\hline B-LDCA & Base - Lower Desert Creek Anhydrite \\
\hline T-LDCMC & Top - Lower Desert Creek Mound Cap \\
\hline B-LDCM & Base - Lower Desert Creek Mound \\
\hline
\end{tabular}


Depositionally, rock units are divided into seals or barriers (anhydrites and shales), mound (carbonate buildup [bafflestones, bindstones, grainstones, and packstones]), and off mound (mudstones and wackestones). Porosity units, and reservoir or potential reservoir layers, are identified within the mound and off-mound intervals. The mound, and some of the offmound units, are part of the "clean carbonate" packages (figures 4 and 5) - intervals containing all of the productive reservoir facies, and where carbonate mudstone and shale are generally absent. The clean carbonate packages abruptly change laterally into thick anhydrite packages, particularly in the upper Ismay zone.

The top and base of all these intervals (seals, mound, clean carbonate, as well as porosity units) were determined and coded as listed in table 1 . The unlisted intervening units represent the baffles or non-reservoir rocks, such as non-porous packestone or wackestone (figures 5 through 8). The mound/mound cap intervals usually have porosity greater than 6 percent, while the clean carbonate intervals are defined by lithology only (such as bafflestone or grainstone), although there may be occasional isolated porosity zones. The top and base of the mound/mound cap intervals are often equivalent to the clean top and base of the clean carbonate intervals. In addition, the top and base of the mound/mound cap intervals may be equivalent to the top and base of the thinner off-mound clean carbonate intervals.

\section{Ismay Isochore Relationships}

\section{Upper Ismay “Clean Carbonate” Isochore Map}

The isochore map of the upper Ismay "clean-carbonate" interval is shown on figure 9. Note that the "thicks" of upper Ismay clean carbonate (the darker green hues on this map) are often connected and nearly surround "thins" (in very pale shades). The thicks are probably the combined effect of upper Ismay platform (middle to inner shelf/tidal flat) deposition and organic (phylloid-algal and bryozoan) buildups. The thins surrounded by thicks are "intra-shelf basins" within the upper Ismay interval. These intra-shelf basins are filled with thick anhydrite deposits (see figure 10, "anhydrite 2" isochore map). The remaining thins that are not surrounded by, or in close proximity to thicks, are largely open-marine (deep, outer shelf) deposits.

\section{Upper Ismay "Anhydrite 2" Isochore Map}

The isochore map of the upper Ismay "anhydrite 2" is shown on figure 10. Note that the areas of thickest anhydrite (in darker shades of orange) roughly correlate with some of the thins on the upper Ismay clean carbonate isochore map (figure 9). The anhydrite 2 thicks were deposited within semi-isolated, intra-shelf basins.

\section{Isochore "Dilemma"}

The isochore relationships shown on the maps in figures 9 and 10 are too coarse or complex to accurately define prospective facies tracts and intra-shelf basin boundaries. Detailed examination of cores tied to geophysical well logs showed that the upper Ismay can be divided into two depositional sequences across the study area. We have termed these packages the "upper part" and "lower part" of the upper Ismay. The top of the lower part is frequently truncated by an exposure or an erosional surface. 


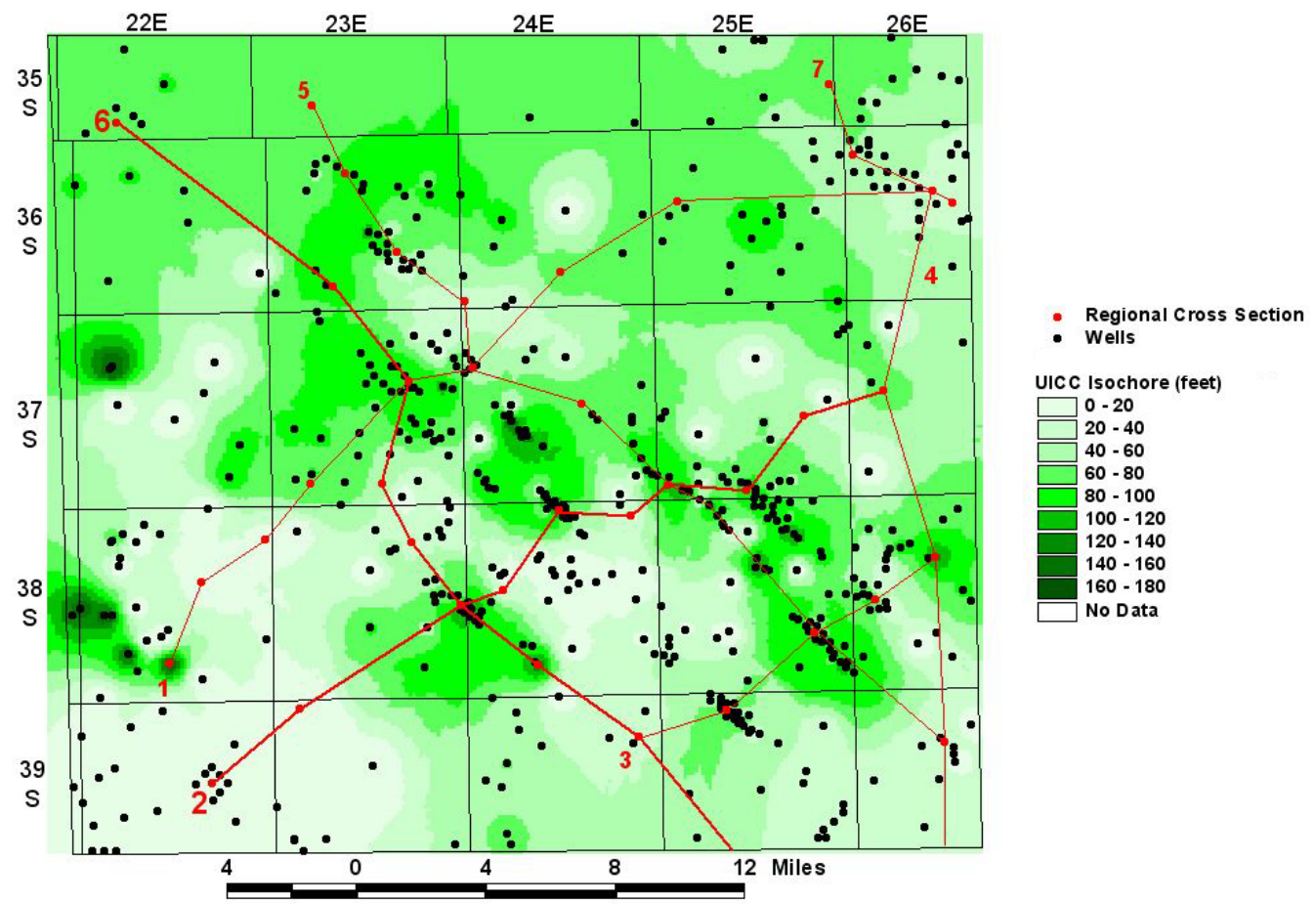

Figure 9. Isochore map of the upper Ismay clean carbonate (UICC) interval. The log picks and correlations of clean carbonate are shown in the regional cross sections (figures 4 and 5).

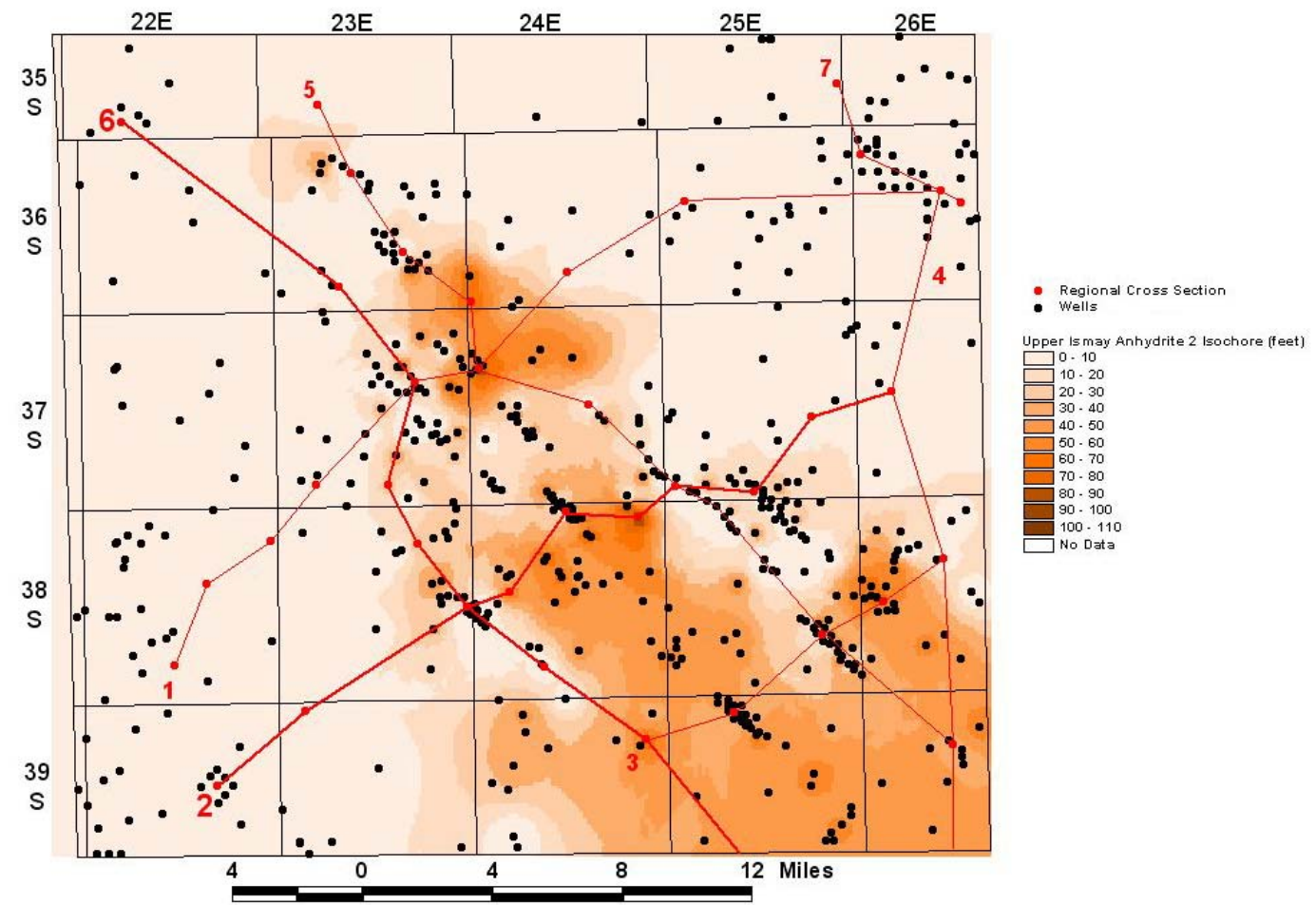

Figure 10. Isochore map of the upper Ismay "anhydrite 2." The log picks and correlations of anhydrite 2 are shown in the regional cross sections (figures 4 and 5). 


\section{Major Facies Mapped in the Upper Ismay and Lower Desert Creek Zones}

Seven depositional facies interpreted from upper Ismay cores and four facies from lower Desert Creek cores have been recognized and mapped across the study area (figures 11 through 13). Mapping of these facies delineates prospective reservoir trends containing porous and productive buildups.

Upper Ismay (both the upper and lower parts as defined above) facies include open marine, middle shelf, inner shelf/tidal flat, bryozoan mounds, phylloid-algal mounds, quartz sand dunes, and anhydritic salinas. Lower Desert Creek facies include open marine, middle shelf, proto-mounds/collapse breccia, and phylloid-algal mounds.

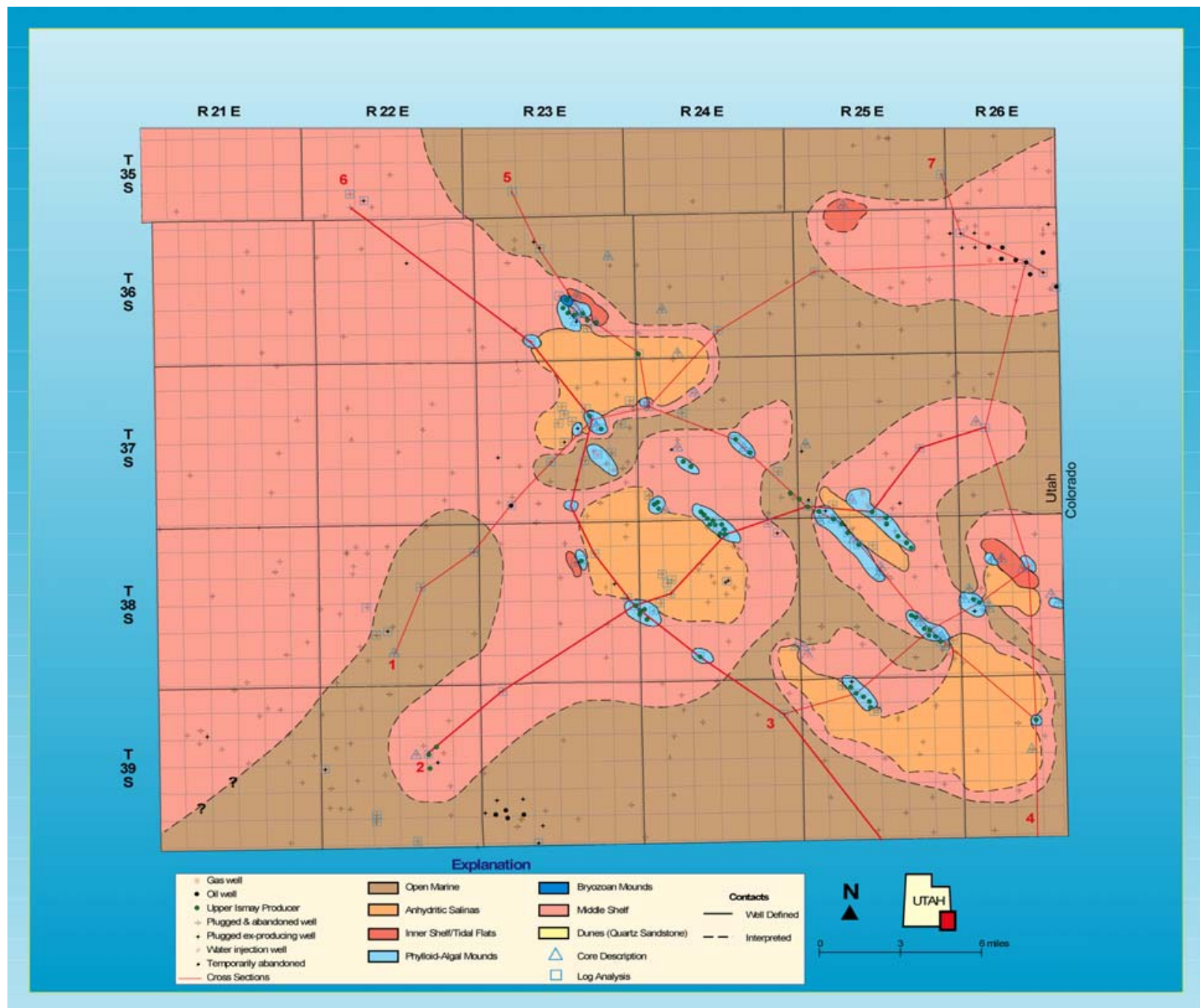

Figure 11. Regional facies map of the upper part of the upper Ismay zone, Paradox Formation, in the Blanding sub-basin, Utah. 


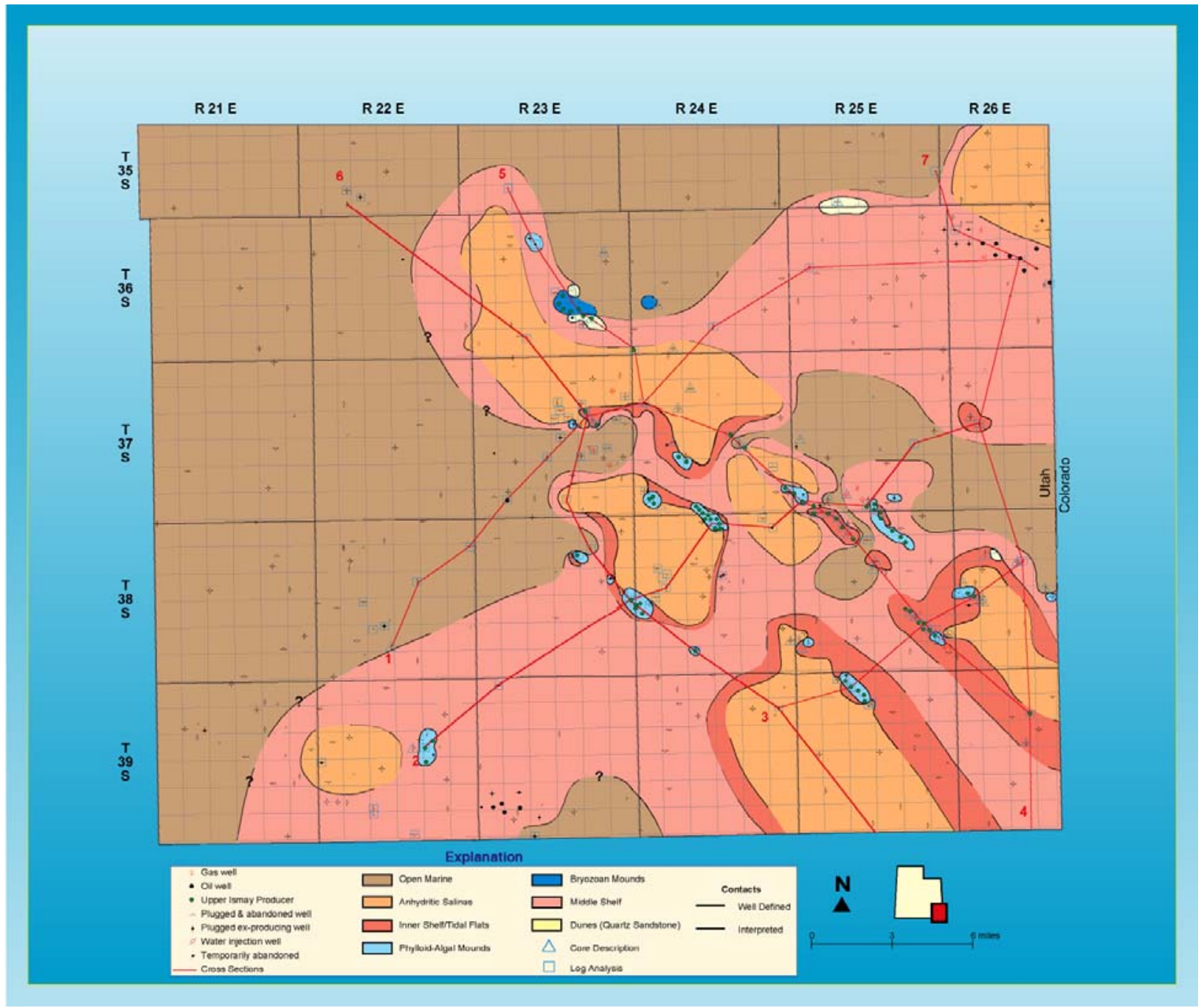

Figure 12. Regional facies map of the lower part of the upper Ismay zone, Paradox Formation, in the Blanding sub-basin, Utah.

\section{Open Marine}

Open-marine facies are found in both the Ismay and Desert Creek zones (figures 11 through 15). This facies consists of lime muds containing well-preserved rugose corals, crinoids, brachiopods, bryozoans, articulated thin-shelled bivalves, and benthic forams indicative of normal marine salinities and low-energy conditions. Rock units with this facies act as barriers and baffles to fluid flow, having very little effective porosity and permeability.

Open-marine facies dominate the lower Desert Creek zone in the Blanding sub-basin where there is very little hydrocarbon potential (figure 13). However, this facies developed in different areas for both the upper part (northeastern and southern regions [figure 11]) and lower part (western to north-central regions [figure 12]) of the upper Ismay zone. 


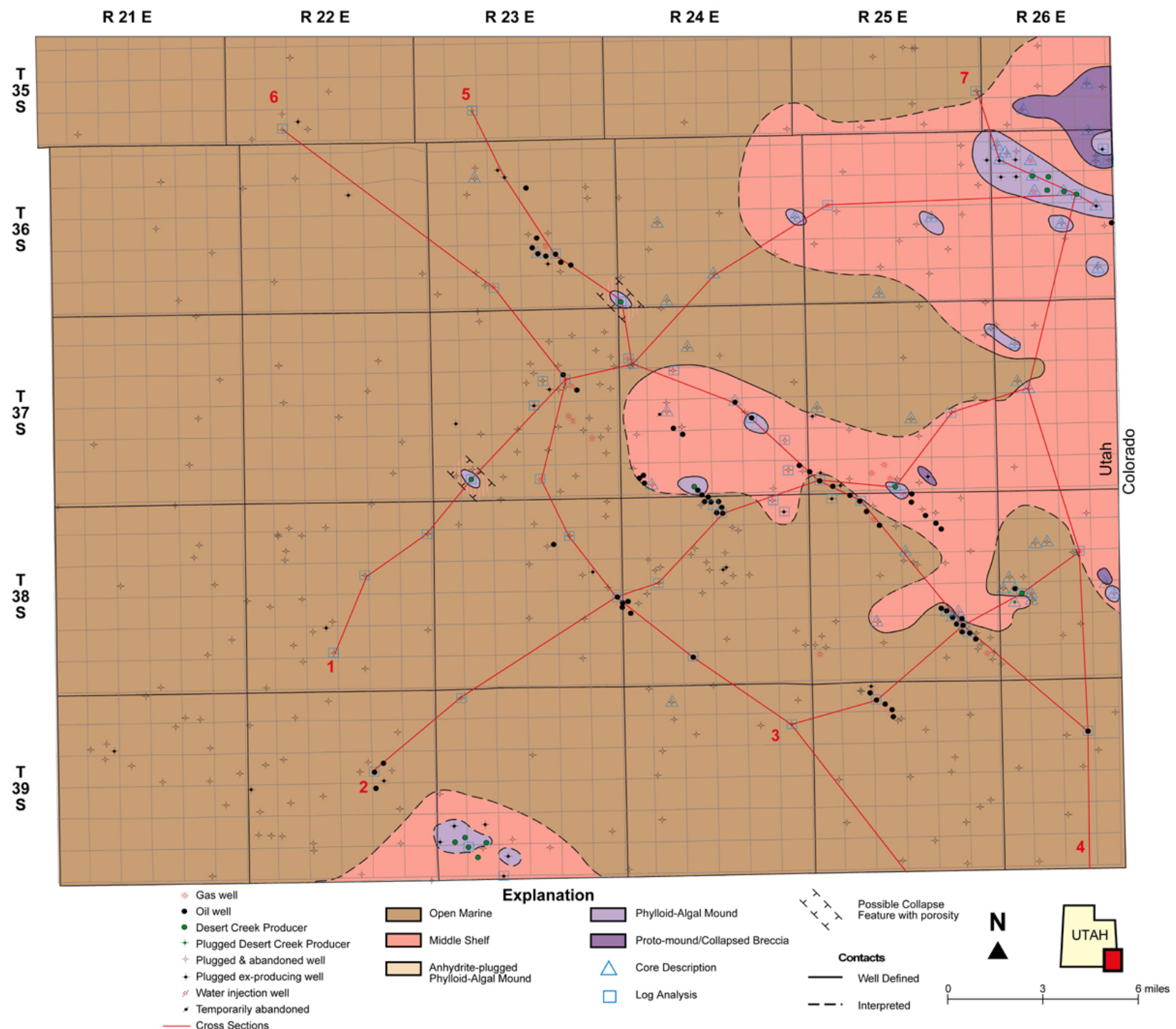

Figure 13. Regional facies map of the lower Desert Creek zone, Paradox Formation, in the Blanding sub-basin, Utah.

\section{Middle Shelf}

Middle-shelf facies are also found in both the Ismay and Desert Creek zones (figure 16). The most common depositional product of this facies is bioturbated lime to dolomitic mudstone with ubiquitous sub-horizontal, feeding burrows. There are few megafossils and little visible matrix porosity. However, there is some fusulinid-rich lime wackestone to packstone also present in very tight, biogenically graded limestone.

Middle-shelf facies cover extensive areas of the upper Ismay zone and surround important intra-shelf basins described later. Bryozoan mounds, quartz sand dunes, protomounds and some phylloid-algal mounds, and inner shelf/tidal flats developed on the lowenergy carbonates of the middle-shelf environment (figures 11 through 13). 

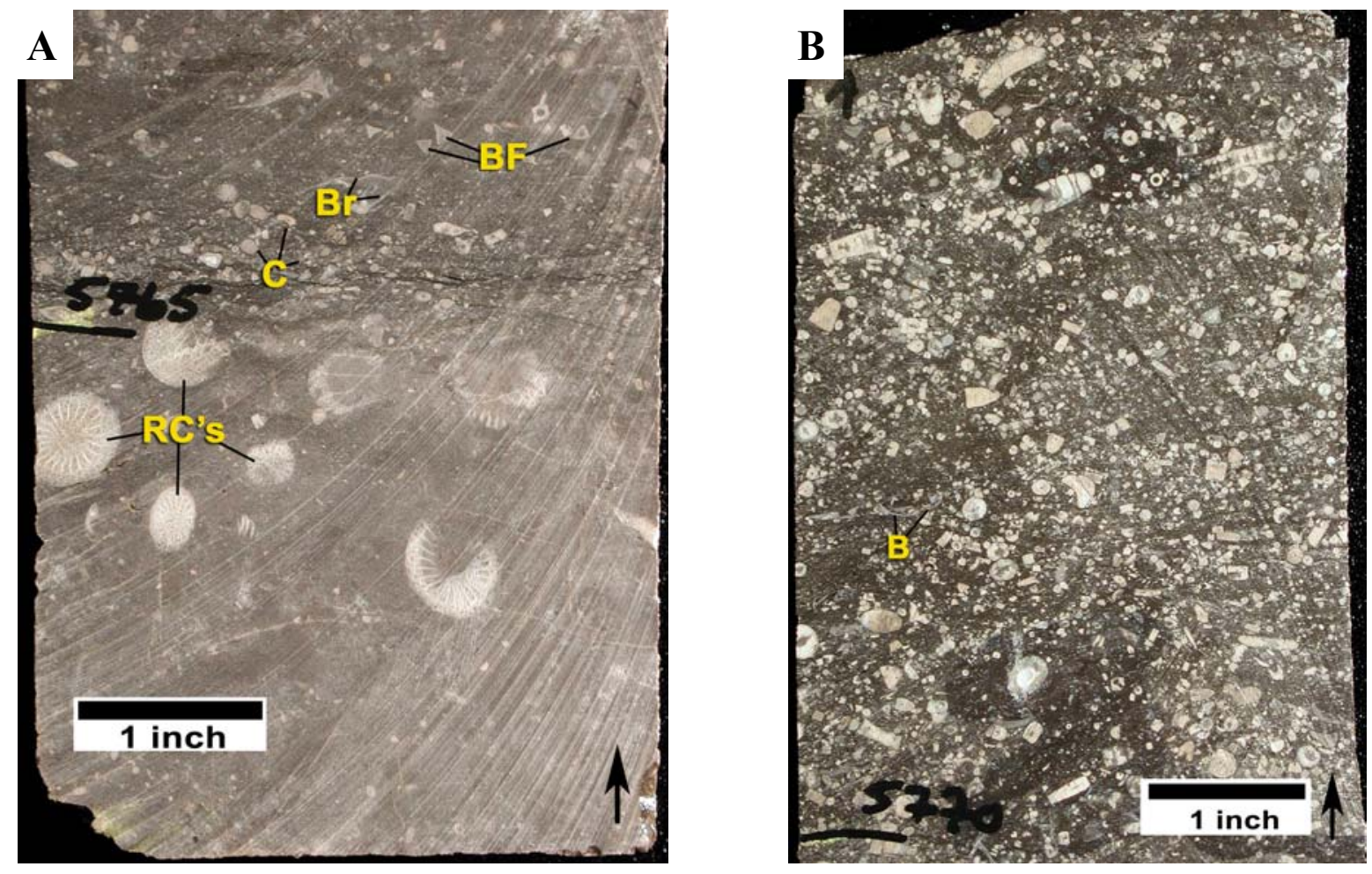

Figure 14. Typical, Ismay, open-marine facies from the No. 1-28 Cuthair well (section 28, T. 38 S., R. 22 E., Salt Lake Base Line [SLBL]). (A) Well-preserved rugose corals (RC), crinoids $(C)$, brachiopods (Br), and benthic forams (BF); slabbed core from 5,765 feet. (B) Well-preserved, partially articulated crinoid stems and parts, as well as articulated thinshelled bivalves (B); slabbed core from 5,770 feet.

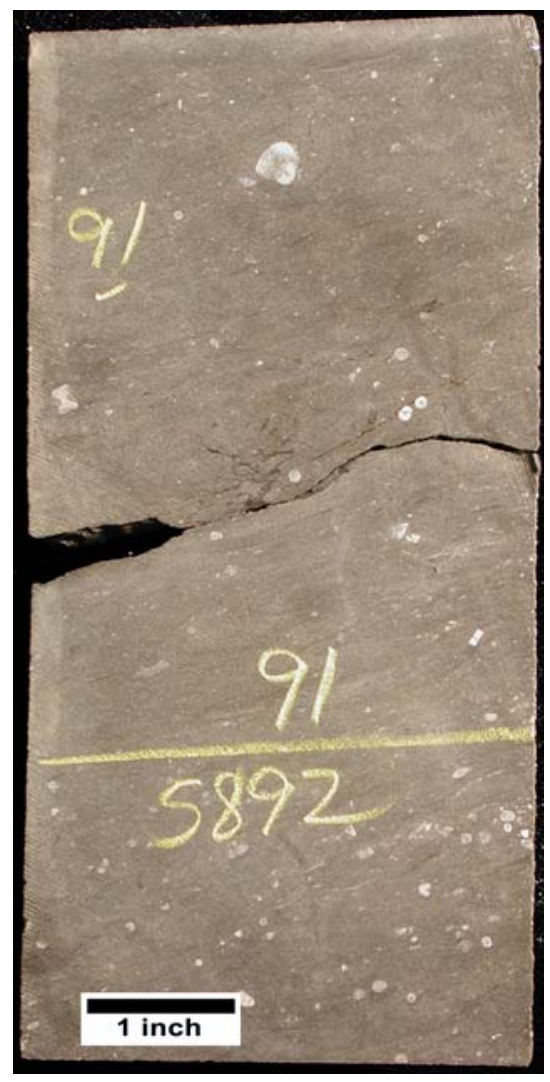

Figure 15. Typical, Desert Creek, open-marine facies from the Scorpion No. 1 well (section 34, T. 36 S., R. 24 E., $S L B L)$ containing dolomitized lime mud, and rugose corals and crinoids; slabbed core from 5,892 feet. 


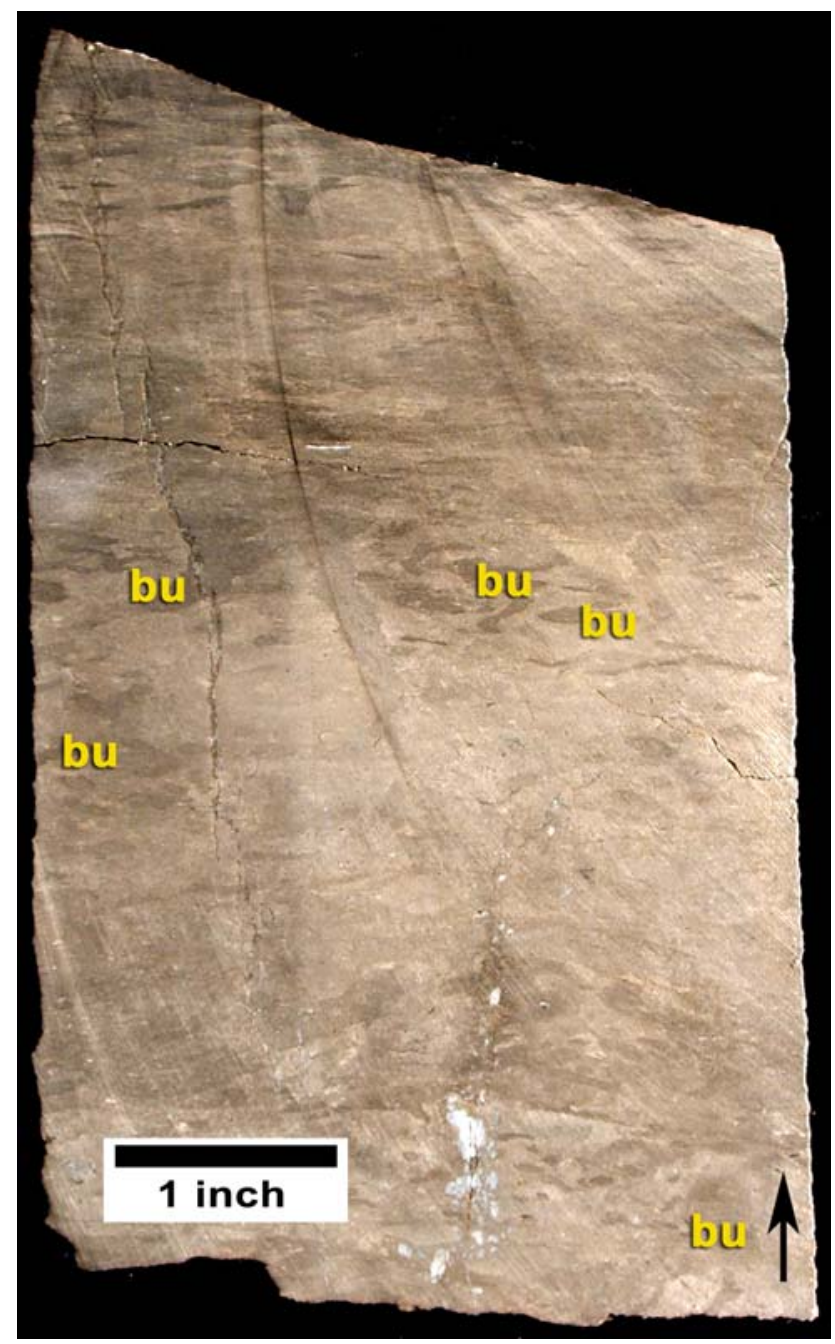

A

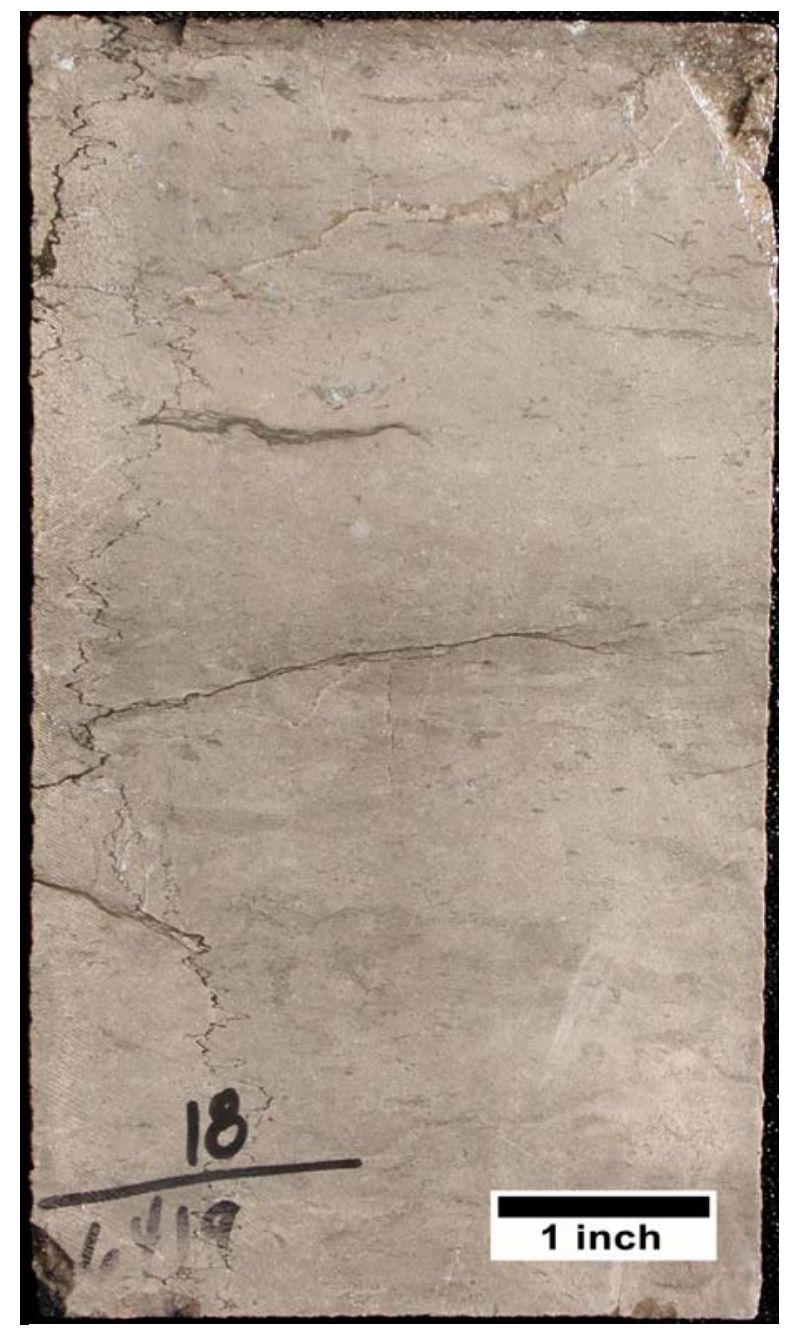

B

Figure 16. Typical middle-shelf facies. (A) Ismay bioturbated lime mudstone containing compacted sub-horizontal feeding burrows (bu); Tank Canyon No. 1-9 well, section 9, T. 37 S., R. 24 E., SLBL, slabbed core from 5,412.5 feet. (B) Desert Creek burrowed dolomitic mudstone; Ucolo No. 1-32 well, section 32, T. 35 S., R. 26 E., SLBL, slabbed core from 6,418.7 feet.

\section{Inner Shelf/Tidal Flat}

Inner shelf/tidal flat facies are found in the Ismay as dolomitized packstone and grainstone (figure 17). Clotted, lumpy, and poorly laminated microbial structures resembling small thrombolites and intraclasts are common. Megafossils and visible porosity are very rare in the inner shelf/tidal flat setting. Non-skeletal grainstone (calcarenite) composed of ooids, coated grains, and "hard peloids" occurs as high-energy deposits in some inner shelf/tidal flat settings. Remnants of interparticle and moldic pores may be present in this facies. 

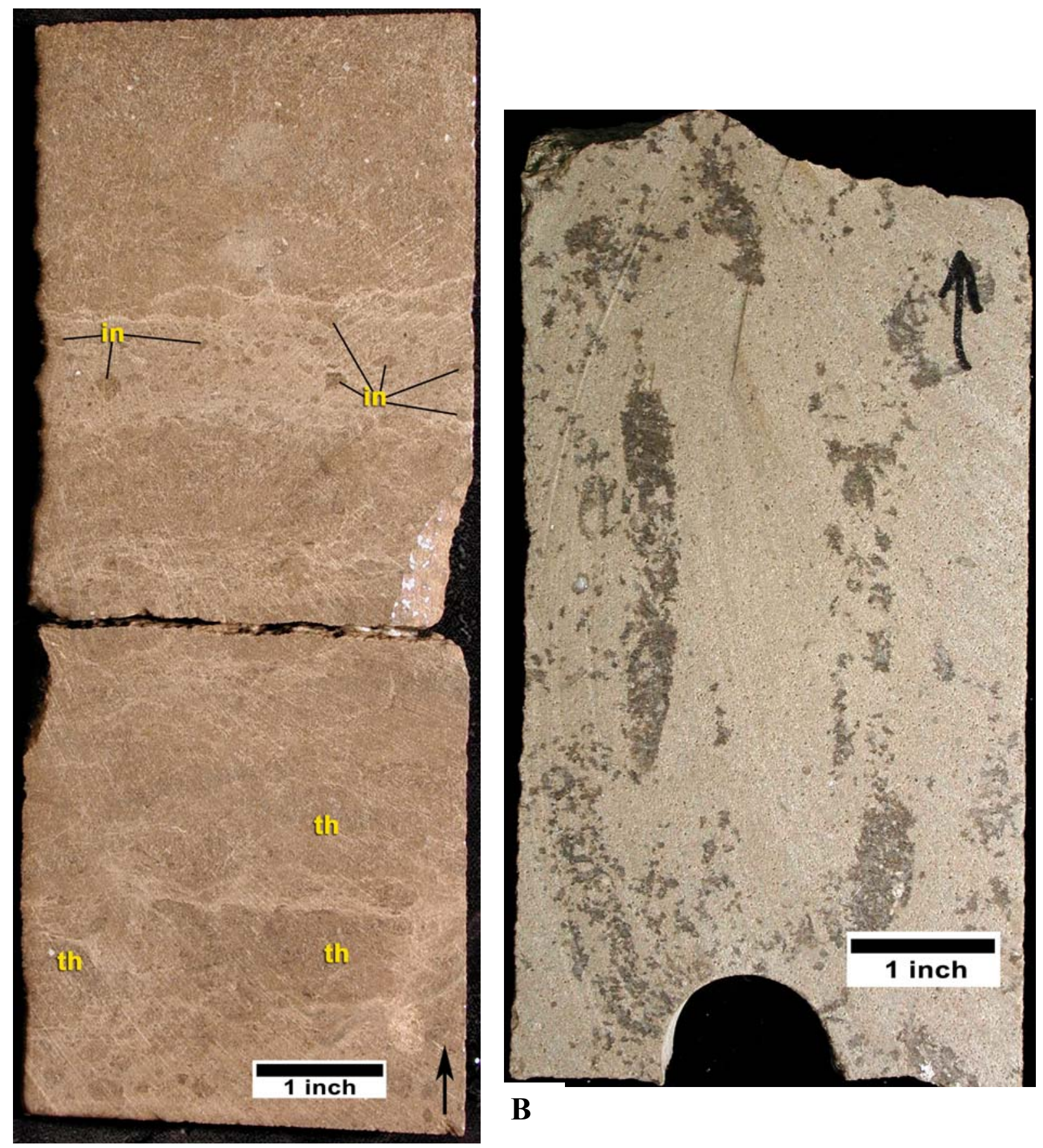

B

A

Figure 17. Typical, Ismay, inner shelf/tidal flat facies. (A) Dolomitized lumpy microbial structures resembling small thrombolites (th) and intraclasts (in) composed of desiccated and redeposited thrombolitic fragments; Tin Cup Mesa No. 2-23 well, section 23, T. 38 S., R. 25 E., SLBL, slabbed core from 5,460.5 feet. (B) Non-skeletal grainstone composed of ooids, coated grains, and peloids, with dark gray patches and columns composed of anhydritecemented sediments; Patterson No. 5 well, section 4, T. 38 S., R. 25 E., SLBL, slabbed core from 5,443.5 feet. 
Inner shelf/tidal flat facies represent relatively small areas in geographical extent, especially in the upper part of the upper Ismay zone. However, recognizing this facies is important because inner shelf/tidal flats often form the substrate for phylloid-algal mound development.

\section{Bryozoan Mounds}

Bryozoan mound facies are found in the Ismay zone as mesh-like networks of tubular and sheet-type (fenestrate) bryozoans (figure 18). These bryozoans provide the binding agent for lime mud-rich mounds. Crinoids and other open-marine fossils are common throughout these quiet-water buildups. Large, tubular bryozoans and marine cement are also common in areas of highenergy, and possibly shallow, water. Porosity is mostly confined to preserved intraparticle spaces.

Bryozoan mound facies developed in the relatively deeper water of the middle shelf. Thus far they are only recognized in the lower part of the upper Ismay, at and near Mustang Flat field (figures 1 and 12).

\section{Proto-Mounds/Collapse Breccia}

Proto-mounds/collapse breccia facies are found in the Desert Creek zone and represent the initial stage of a mound buildup or one that never fully developed (figure 19). They contain dolomitized and brecciated algal plates, marine cements, and internal sediments suggesting subareal exposure.

Proto-mounds/collapse breccia facies are usually near phylloid-algal mound facies but generally lack any significant porosity. They may appear as promising buildups on seismic but in actuality have little potential other than as guides to nearby fully developed mounds (figure 13).

Figure 18. Typical, Ismay, bryozoan-mound facies from the Mustang No. 3 well (section 26, T. 36 S., $R$. 25 E., SLBL, slabbed core from 6,171 feet) containing large tubular bryozoans (Bry) and "lumps" of marine cement (cem). Occasional phylloid-algal plates are also present. This mound fabric is typical of higher energy, and possibly shallower water than the mud-dominated fabrics.

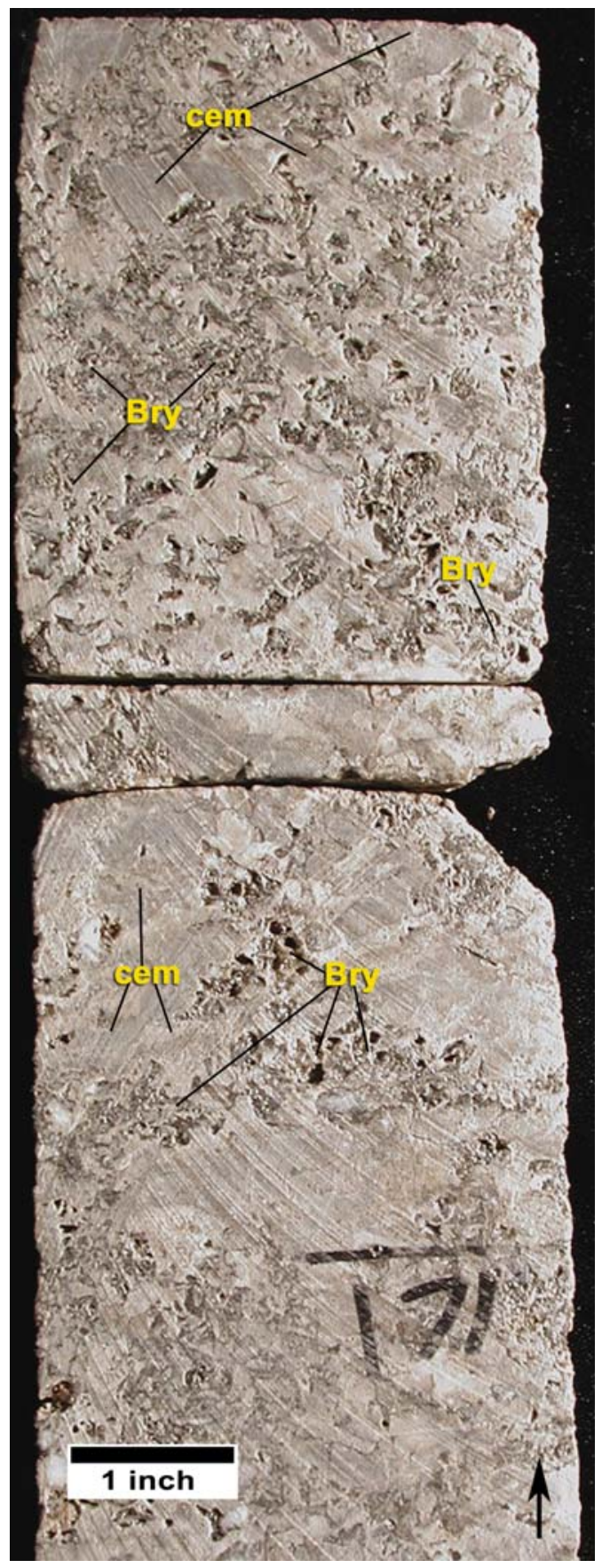




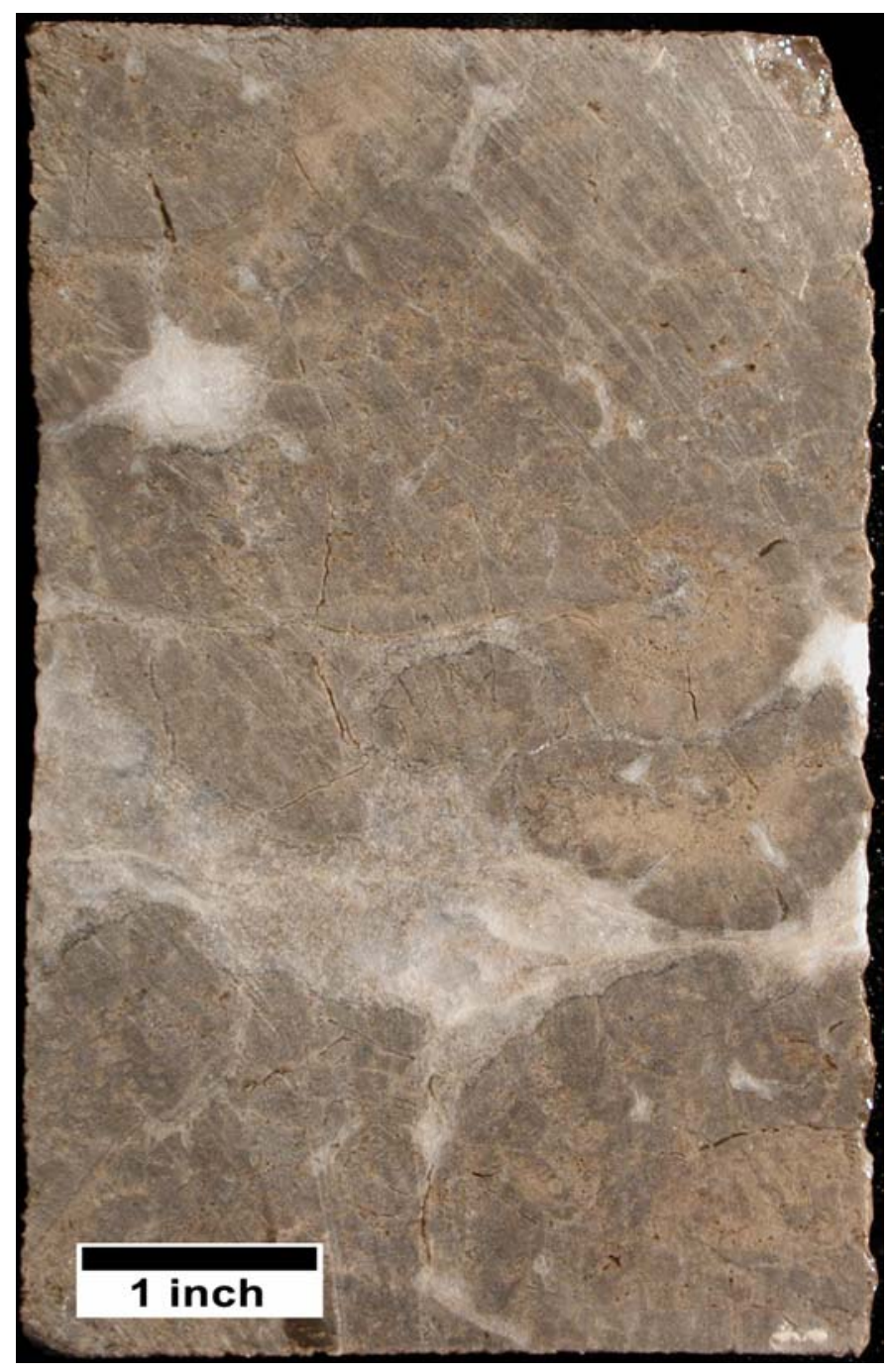

Figure 19. Typical, Desert Creek protomound/collapse breccia from the Ucolo No. 1 well (section 26, T. 38 S., R. 25 E., SLBL, slabbed core from 5,506 feet) showing dolomitized, broken algal plates, marine cement, and internal sediment. Note that very little porosity is preserved (white areas are anhydrite).

\section{Phylloid-Algal Mounds}

Phylloid-algal mound facies are found in both the Ismay and Desert Creek zones and represent the dominant oil-producing reservoirs in the Paradox Formation (figures 11 through 13, and 20). Very large phylloid-algal plates of the codiacean green algae Ivanovia (the dominant genus in the Ismay zone) and skeletal grains create bafflestone or bindstone fabrics. In mound interiors, algal plates are commonly found in near-growth positions surrounded by lime mud (figure 20A). On the high-energy margins of algal mounds, algal plates and skeletal grains serve as substrates for substantial amounts of botryoids and other early-marine cements, and internal sediments (figure 20B). Desert Creek mounds are dolomitized, contain plates of the codiacean green algae Kansasphyllum (figure 20C), and show evidence of subaerial exposure (breccia or beach rock). Pore types include primary shelter pores preserved between phylloid-algal plates and secondary moldic pores.

In the upper Ismay zone, most phylloid-algal mounds developed adjacent to widespread intra-shelf (anhydrite-filled) basins (figures 11 and 12). Porous Desert Creek mound facies, such as the reservoir for Bug field, appear to be linear shorelines that developed on the middle shelf (figure 13). 


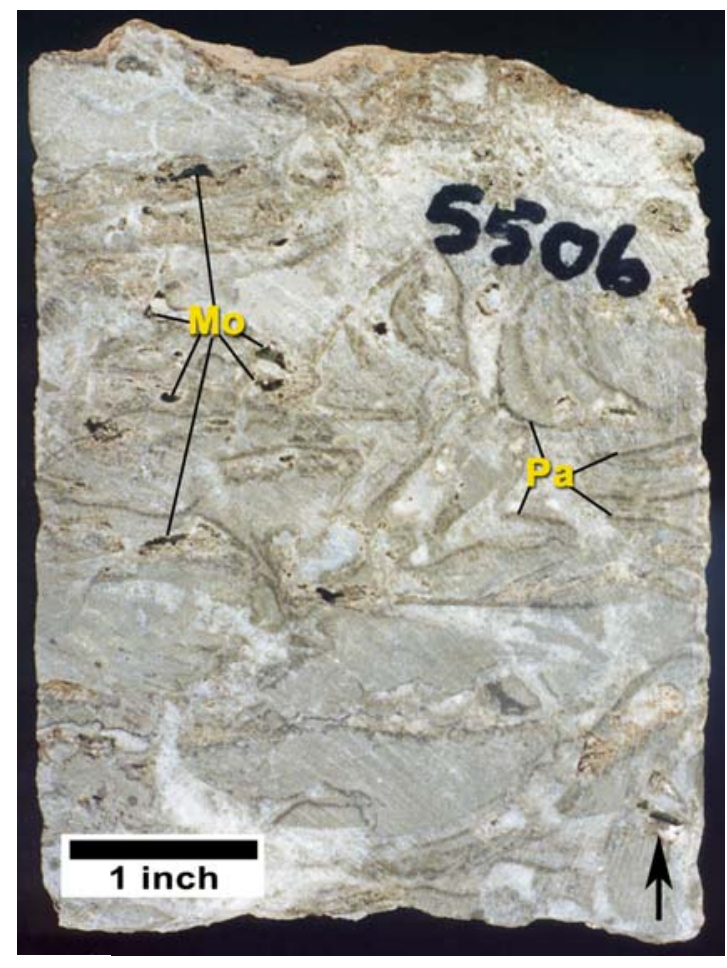

A

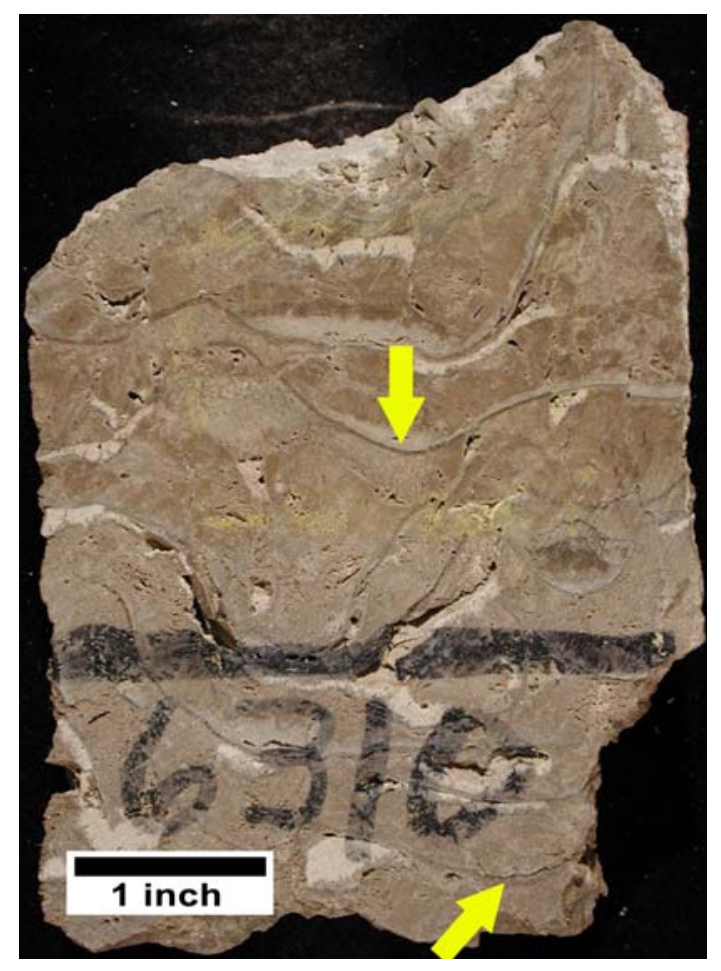

C

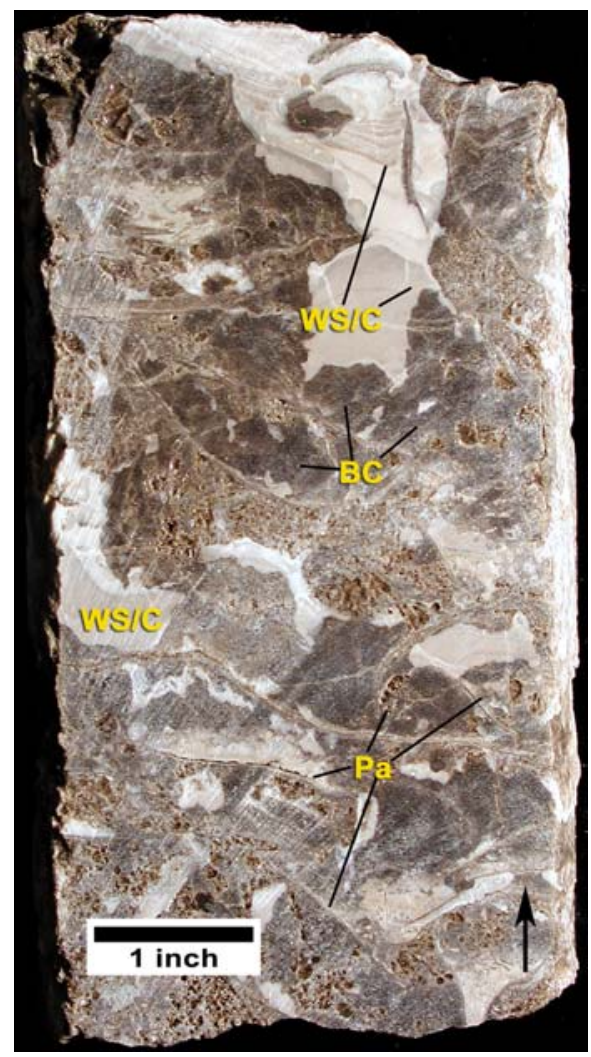

Figure 20. Typical Ismay and Desert Creek phylloidalgal mound facies. (A) Ismay bafflestone fabric in the Tin Cup Mesa No. 3-26 well (section 26, T. 38 S., R. 25 $E$., SLBL, slabbed core from 5,506 feet) showing large phylloid-algal plates (Pa) in near-growth positions surrounded by light gray lime muds. Note the scattered moldic pores (Mo) that appear black here. (B) Ismay bindstone (cementstone) from the Bonito No. 41-6-85 well (section 6, T. 38 S., R. 25 E., SLBL, slabbed core from 5,590.5 feet) showing very large phylloid-algal plates (Pa), loose skeletal grains, and black marine botryoids (BC) as well as light brown, banded, internal sediments and marine cements $(\mathrm{WS} / \mathrm{C})$. Note the patches of preserved porosity within coarse skeletal sediments between algal plates. (C) Desert Creek mound from the May Bug No. 2 well (section 7, T. 36 S., R. 26 E., SLBL, slabbed core from 6,310 feet) composed of dolomitized algal plates of the genus Kansasphyllum (arrows). 


\section{Quartz Sand Dunes}

Quartz sand dune facies are found in the Ismay as very fine grained, well-sorted quartzose sandstone that display moderate- to high-angle cross-bedding (figure 21). The well-rounded nature of the individual quartz sand grains (visible in thin sections) is consistent with a possible eolian origin for these dunes, although the source of the sand is uncertain.

Quartz sand dune facies are present near Mustang Flat field and a few other isolated locations in the lower part of the upper Ismay zone (figure 12). This facies may also be present in the lower Ismay outcrop along the Honaker Trail in the San Juan River canyon near Goosenecks State Park, southern San Juan County, Utah (Pray and Wray, 1963).

\section{Anhydritic Salinas}

Anhydite salina facies are found within locally thick accumulations in upper Ismay (upper and lower parts) intra-shelf basins (figures 11 and 12). Anhydrite growth forms include nodular-mosaic ("chicken-wire"), palmate, and banded anhydrite (figure 22). Large palmate crystals probably grew in a gypsum aggregate indicative of subaqueous deposition. Detrital and chemical evaporites (anhydrite) filled in the relief around palmate structures. Thin, banded couplets of pure anhydrite and dolomitic anhydrite are products of very regular chemical changes in the evaporite intra-shelf basins. These varve-like couplets are probably indicative of relatively "deep-water" evaporite precipitation.

Regional facies mapping clearly defines anhydrite-filled, intra-shelf basins. Inner shelf/tidal flat and associated productive, phylloid-algal, moundfacies trends of the Ismay are present around the anhydritic salinas of intra-shelf basins (figures 11 and 12). Although not present in the lower Desert Creek zone in the Blanding sub-basin, the Desert Creek reservoir facies peripheral to Greater Aneth field to the south (figure 1) wrap around similar anhydrite-filled intra-shelf basins (Chidsey and others, 1996; Chidsey and Eby, 2000).

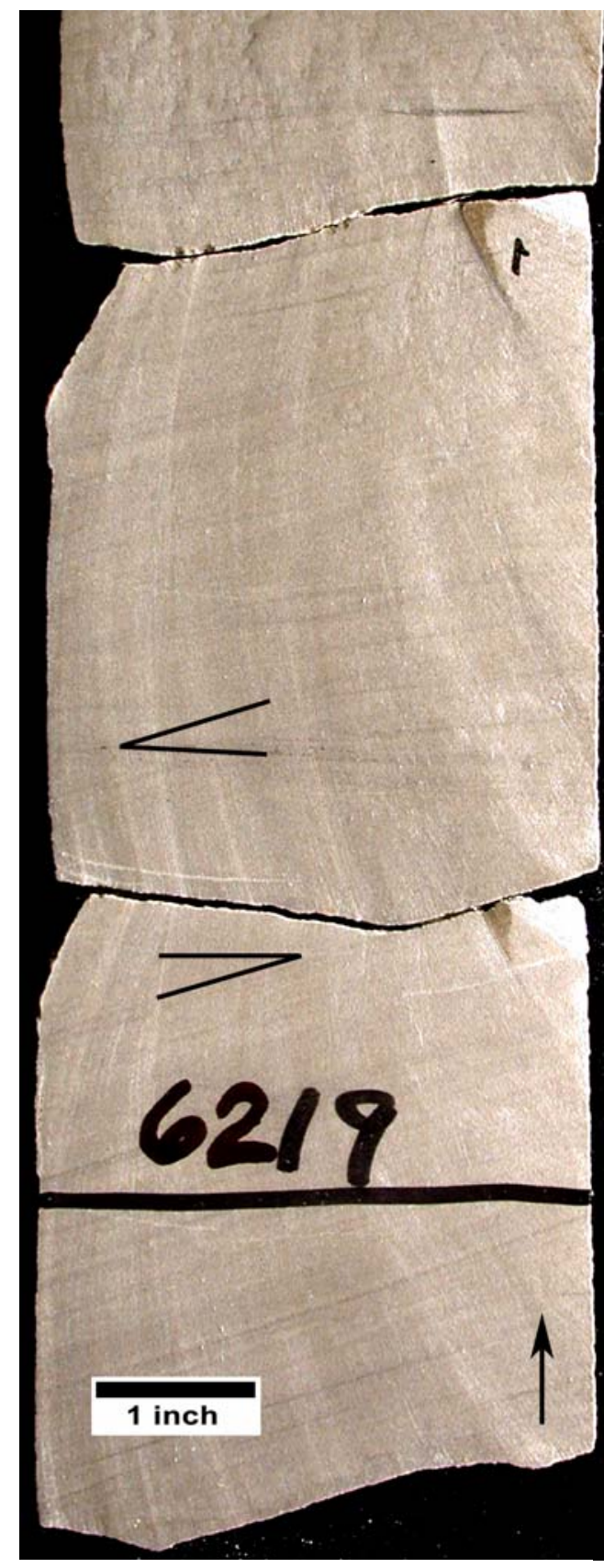

Figure 21. Typical upper Ismay (lower part) quartz sand dune facies from the Mustang No. 22-43 well (section 26, T. 36 S., R. 43 E. SLBL, slabbed core from 6,219 feet) showing high-angle crossstratification within a 35-foot-thick sandstone encountered in wells of Mustang Flat field (figure 1). 


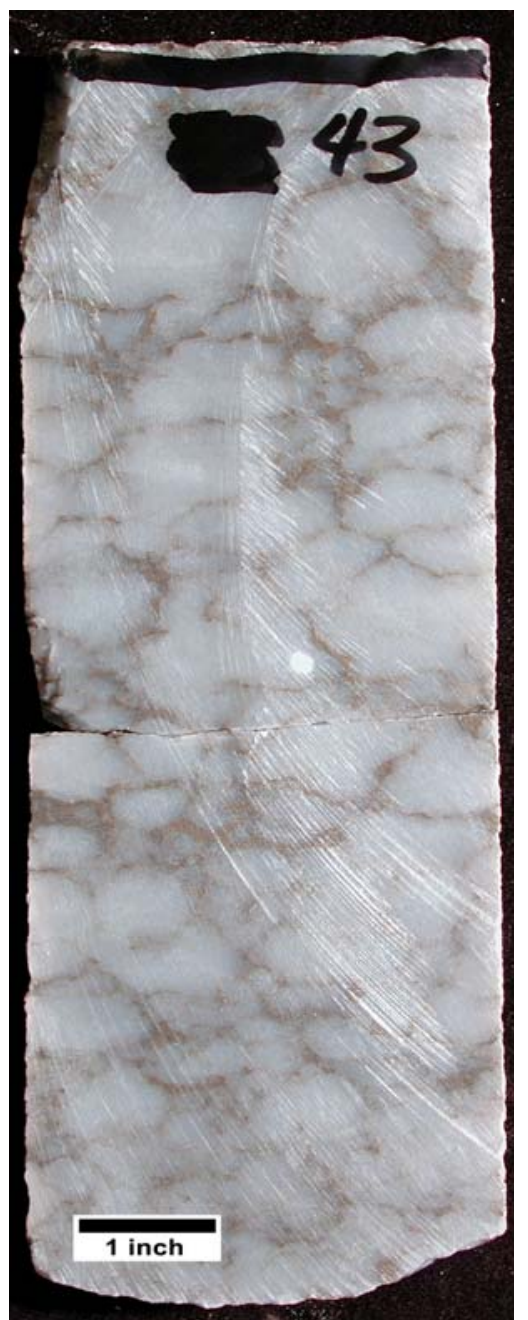

A

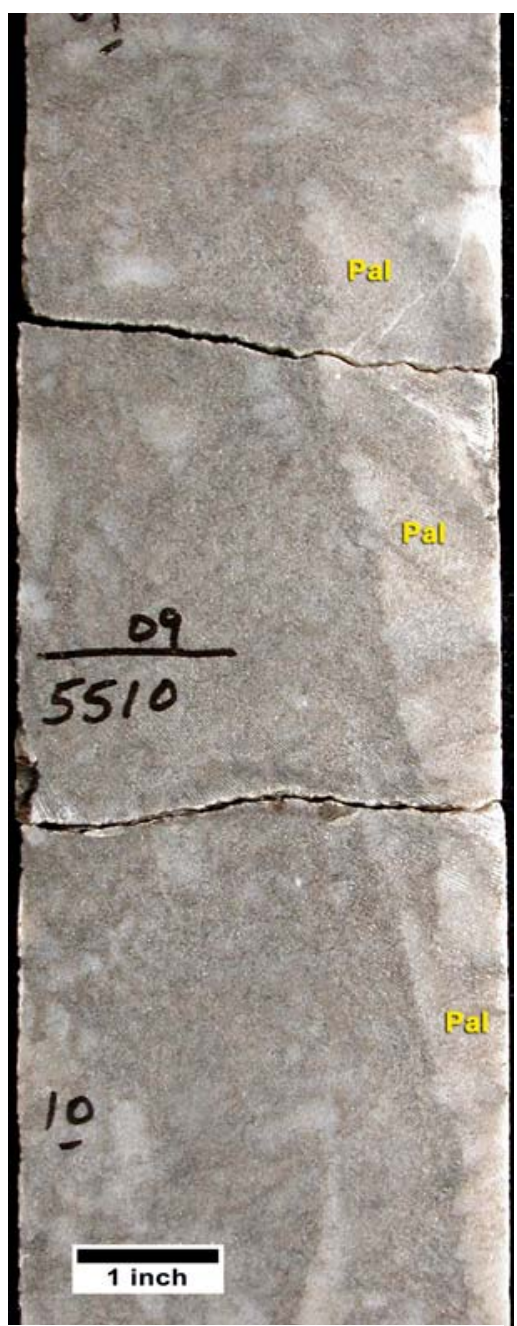

B

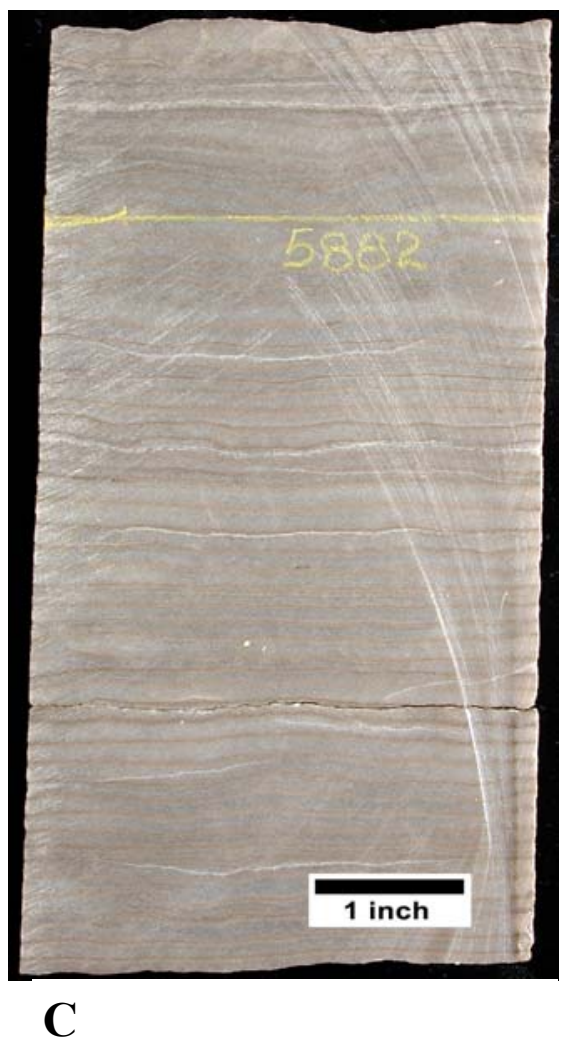

Figure 22. Anhydrite growth forms typically found in anhydrite salina facies of upper Ismay intra-shelf basins. (A) Nodular-mosaic ("chicken-wire") anhydrite; Tank Canyon No. 1-9 well, section 9, T. 37 S., R. 24 E. SLBL, slabbed core from 5,343 feet. (B) Large palmate crystals of anhydrite (Pal) along the right margin of this core segment probably grew in a gypsum aggregate that resembled an inverted candelabra while the remainder of the core segment consists of detrital and chemical anhydrite that filled in the relief around the palmate structure; Sioux Federal No. 30-1 well, section 30, T. 38 S., R. 25 E., SLBL, slabbed core from 5,510 feet. (C) Thin (cm-scale), banded couplets of pure anhydrite (white to light gray) and dolomitic anhydrite (brown); Montezuma No. 41-17-74, section 17, T. 37 S., R. 24 E., SLBL, slabbed core from 5,882 feet. 


\section{TECHNOLOGY TRANSFER}

The UGS is the Principal Investigator and prime contractor for three governmentindustry cooperative petroleum-research projects, including two in the Paradox Basin. These projects are designed to improve recovery, development, and exploration of the nation's oil and gas resources through use of better, more efficient technologies. The projects involve detailed geologic and engineering characterization of several complex heterogeneous reservoirs. The two Class II Oil (this report covers the Class II Revisit project) projects include practical oilfield demonstrations of selected technologies in the Paradox Basin. The third project involves establishing a log-based correlation scheme for the Tertiary Green River Formation in the southwestern Uinta Basin to help identify new plays and improve the understanding of producing intervals. The DOE and multidisciplinary teams from petroleum companies, petroleum service companies, universities, private consultants, and state agencies are cofunding the three projects. The UGS is also the Principal Investigator and prime contractor for the DOE Preferred Upstream Management (PUMP II) project titled Major Oil Plays in Utah and Vicinity which will describe and delineate oil plays in the Thrust Belt, Uinta Basin, and Paradox Basin.

The UGS will release selected products of the Paradox Basin project in a series of formal publications. These publications may include data, as well as the results and interpretations. Syntheses and highlights will be submitted to refereed journals, as appropriate, such as the American Association of Petroleum Geologists (AAPG) Bulletin and Journal of Petroleum Technology, and to trade publications, such as the Oil and Gas Journal. This information will also be released through the UGS periodical Survey Notes and be posted on the UGS Paradox Basin project Internet web page.

The Technical Advisory Board advises the technical team on the direction of study, reviews technical progress, recommends changes and additions to the study, and provides data. The Technical Advisory Board is composed of 13 field operators from the Paradox Basin (Seeley Oil Co., Legacy Energy Corp., Pioneer Oil \& Gas, Hallwood Petroleum Inc., Dolar Oil Properties, Cochrane Resources Inc., Wexpro Co., Samedan Oil Corp., Questar Exploration, Tom Brown Inc., PetroCorp Inc., Stone Energy LLC., and Sinclair Oil Corp.). This board ensures direct communication of the study methods and results to the Paradox Basin operators. The Stake Holders Board is composed of groups that have a financial interest in the study area including representatives from the Utah and Colorado state governments (Utah School and Institutional Trust Lands Administration, Utah Division of Oil, Gas and Mining, and Colorado Oil and Gas Conservation Commission), Federal Government (U.S. Bureau of Land Management and U.S. Bureau of Indian Affairs), and the Ute Mountain Ute Indian Tribe. The members of the Technical Advisory and Stake Holders Boards receive all semi-annual technical reports and copies of all publications, and other material resulting from the study.

The UGS prepared a short course, "Pennsylvanian Heterogeneous Shallow-Shelf Buildups of the Paradox Basin: A Core Workshop," for the 2003 AAPG convention, May 10, 2003. The short course was co-sponsored by the DOE. Core from representative Ismay and Desert Creek fields was examined. All core displayed was placed into regional paleogeographic settings. The core workshop was organized into topical modules with participants performing a series of exercises using core, geophysical well logs, and photomicrographs from thin sections. These modules included: describing reservoir vs. nonreservoir facies, determining diagenesis and porosity from core, recognizing barriers and baffles 
to fluid flow, correlating core to geophysical well logs, and identifying potential completion zones and candidates for horizontal drilling.

\section{Utah Geological Survey Survey Notes and Internet Web Site}

The purpose of Survey Notes is to provide non-technical information on contemporary geologic topics, issues, events, and ongoing UGS projects to Utah's geologic community, educators, state and local officials and other decision makers, and the public. Survey Notes is published three times yearly. Single copies are distributed free of charge and reproduction (with recognition of source) is encouraged. The UGS maintains a database that includes those companies or individuals (more than 300 as of April 2003) specifically interested in the Paradox Basin project or other DOE-sponsored UGS projects. They receive Survey Notes and notification of project publications and workshops.

The UGS maintains a web site on the Internet, http://geology.utah.gov. The UGS site includes a page under the heading Economic Geology Program, which describes the UGS/DOE cooperative studies (Paradox Basin, Ferron Sandstone, Bluebell field, Green River Formation, PUMP II), and has a link to the DOE web site. Each UGS/DOE cooperative study also has its own separate page on the UGS web site. The Paradox Basin project page http://geology.utah. gov/emp/Paradox 2/index.htm contains: (1) a project location map, (2) a description of the project, (3) a list of project participants and their postal addresses and phone numbers, (4) a reference list of all publications that are a direct result of the project, and (5) semi-annual technical progress reports.

\section{Technical Presentation}

The following technical presentation was made during the second six months of the third project year as part of the technology transfer activities.

"Heterogeneous Shallow-Shelf Carbonate Buildups in the Paradox Basin, Utah and Colorado: Targets for Increased Oil Production and Reserves Using Horizontal Drilling Techniques" by Thomas C. Chidsey, Jr., at a Class II Review conference sponsored by the National Energy Technology Laboratory at the Center for Energy and Economic Diversification (CEED) in Odessa, Texas, December 12, 2002. Core photographs, SEM, pore casts, photomicrographs, capillary pressure/mercury injection graphs, maps, diagenetic analysis, and horizontal drilling recommendations were part of the presentation.

\section{Project Publication}

Chidsey, T.C., Jr., 2002, Heterogeneous shallow-shelf carbonate buildups in the Paradox Basin, Utah and Colorado: targets for increased oil production and reserves using horizontal drilling techniques - semi-annual technical progress report for the period April 6, 2002 to October 5, 2002: U.S. Department of Energy, DOE/BC15128-5, 35 p. 


\section{CONCLUSIONS}

The Blanding sub-basin within the Pennsylvanian Paradox Basin developed on a shallow-marine shelf that locally contained algal-mound and other carbonate buildups. The two main producing zones of the Paradox Formation are the Ismay and the Desert Creek. The Ismay zone is dominantly limestone comprising equant buildups of phylloid-algal material. The Desert Creek zone is dominantly dolomite comprising regional nearshore-shoreline trends with highly aligned, linear facies tracts. This study was undertaken to provide a useful database and methodology for identifying potential horizontal drilling targets within heterogeneous carbonate rocks containing porous phylloid-algal buildups and associated facies.

A grid of regional $\log$ cross sections within the Utah portion of the Blanding sub-basin shows the development of "clean carbonate" packages that contain all of the productive reservoir facies. These clean carbonates abruptly change laterally into thick anhydrite packages. Isochore maps of the upper Ismay clean carbonates and the locally thick anhydrites are consistent with a broad carbonate shelf containing several small intra-shelf basins. The intra-shelf basin centers filled with anhydrite following carbonate sedimentation on the remainder of the carbonate shelf.

Examination of upper Ismay cores identified seven depositional facies: open marine, middle shelf, inner shelf/tidal flat, bryozoan mounds, phylloid-algal mounds, quartz sand dunes, and anhydritic salinas. Lower Desert Creek facies include open marine, middle shelf, protomounds/collapse breccia, and phylloid-algal mounds.

Mapping the upper Ismay zone facies into two intervals (upper and lower parts) delineates very prospective reservoir trends that contain porous, productive buildups. The mapped facies trends clearly define anhydrite-filled intra-shelf basins (figure 23). Facies and reservoir controls imposed by the anhydritic intra-shelf basins should be considered when selecting the optimal location and orientation of any horizontal drilling for undrained reserves, as well as identifying new exploration trends. Projections of the inner shelf/tidal flat and mound trends around the intra-shelf basins identify potential exploration targets, which could be developed using horizontal drilling techniques (figure 24). Drilling horizontally from known phylloid-algal reservoirs along the inner shelf/tidal flat trend could encounter previously undrilled porous buildups.

Intra-shelf basins are not present in the lower Desert Creek zone of the Blanding subbasin. However, drilling horizontally from productive mound facies along linear shoreline trends could also encounter previously undrilled porous Desert Creek intervals and buildups.

\section{ACKNOWLEDGMENTS}

Funding for this ongoing research was provided as part of the Class II Oil Revisit Program of the U.S. Department of Energy, National Petroleum Technology Office, Tulsa, Oklahoma, contract number DE-FC26-00BC15128. The Contracting Officer's Representative is Gary D. Walker. Support was also provided by the Colorado Geological Survey and David E. Eby, Eby Petrography \& Consulting, Inc.

Core and petrophysical data were provided by Burlington Resources, Anadarko Petroleum Company, Wexpro Company, Seeley Oil Company, Marathon Oil Company, and Samedan Oil Corporation. Core descriptions also incorporated interpretations by Carl R. 


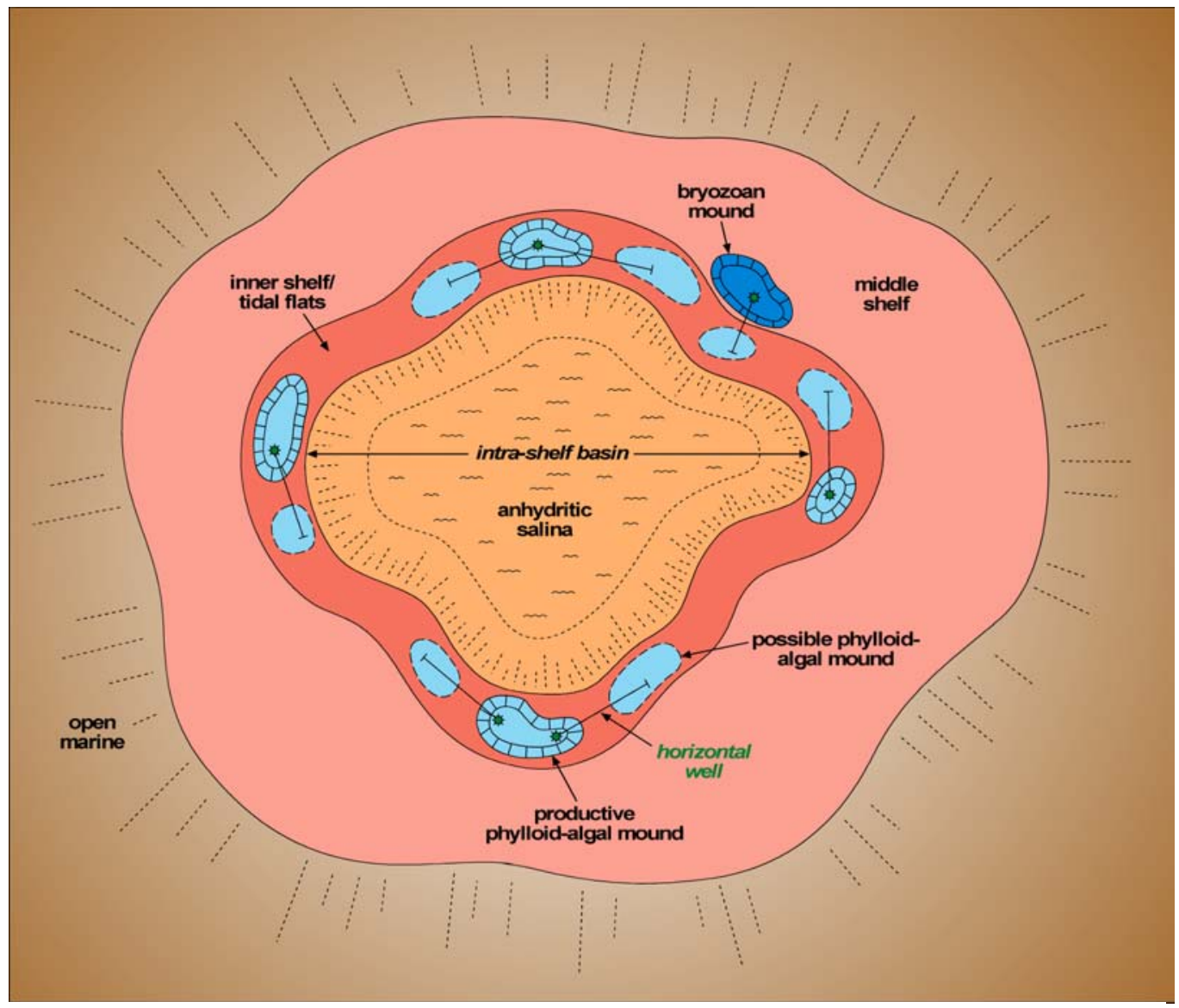

Figure 23. Map view of an ideal upper Ismay intra-shelf basin surrounded by a ring of inner shelf/tidal flat sediments (shown in red) which encase phylloid-algal mound clusters (in light blue). The central portion of the intra-shelf basin is the location of thick anhydrite (in orange) accumulation. Outboard from the inner shelf/tidal flat and mound fairway are low-energy middle-shelf and open-marine carbonates.

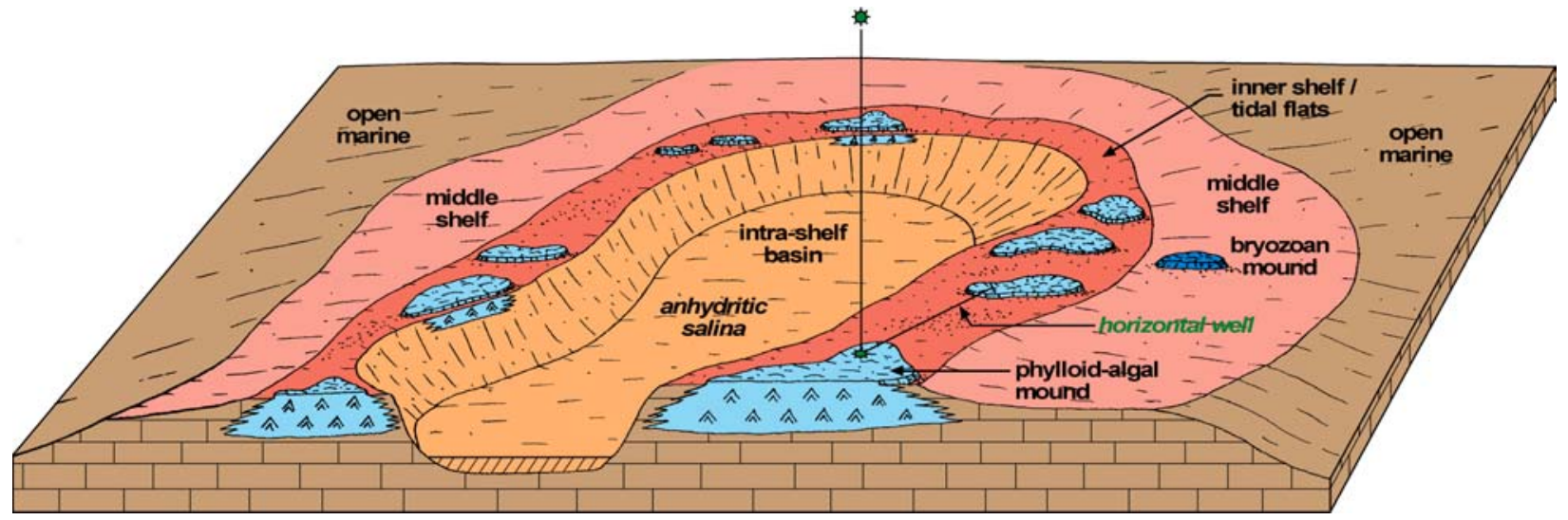

Figure 24. Cut-away block diagram showing the possible spatial relationships of upper Ismay facies types controlled by an intra-shelf basin. Phylloid-algal mounds (in light blue) are the principal reservoir within a curvilinear band that rims the intra-shelf basin. $A$ hypothetical vertical well into a known mound reservoir is used as a kick-off location for horizontal drilling into previously undrained mounds. 
Cannizzaro, M. Randal Skinner, and Michael H. Roylance. Jim Parker, Carolyn Olsen, and Tom Dempster of the Utah Geological Survey, drafted figures and photographed core. The report was reviewed by David Tabet and Michael Hylland of the Utah Geological Survey. Cheryl Gustin, Utah Geological Survey, formatted the manuscript.

\section{REFERENCES}

Chidsey, T.C., Jr., Eby, D.E., and Lorenz, D.M., 1996, Geological and reservoir characterization of small shallow-shelf fields, southern Paradox Basin, Utah, in Huffman, A.C., Jr., Lund, W.R., and Godwin, L.H., editors, Geology and resources of the Paradox Basin: Utah Geological Association Publication 25, p. 39-56.

Chidsey, T.C., Jr., and Eby, D.E., 2000, Facies of the Paradox Formation, southeastern Utah, and modern analogs - tools for exploration and development [abs.]: American Association of Petroleum Geologists, Annual Convention Program with Abstracts, v. 9, p. A26.

Pray, L.C, and Wray, J.L., 1963, Porous algal facies (Pennsylvanian) Honaker Trail, San Juan Canyon, Utah, in Bass, R.O., editor, Shelf carbonates of the Paradox Basin: Four Corners Geological Society Guidebook, p. 204-234. 